NBER WORKING PAPER SERIES

\title{
INTERNATIONAL BANKING AND CROSS-BORDER EFFECTS OF REGULATION: LESSONS FROM THE UNITED STATES
}

\author{
Jose Berrospide \\ Ricardo Correa \\ Linda Goldberg \\ Friederike Niepmann \\ Working Paper 22645 \\ http://www.nber.org/papers/w22645 \\ NATIONAL BUREAU OF ECONOMIC RESEARCH \\ 1050 Massachusetts Avenue \\ Cambridge, MA 02138 \\ September 2016
}

The authors thank Jacob Conway and Eric Parolin for excellent research assistance. We also thank anonymous referees, Sirio Aramonte, Stijn Claessens, Valeriya Dinger, Kebin Ma, Marcus Pramor, Jana Ohls, Tim Schmidt-Eisenlohr and participants at the 2016 IBEFA summer meeting and the Norges Bank's Financial Stability and Macroprudential Policy workshop for very useful feedback. The views expressed in this paper are solely those of the authors and should not be interpreted as reflecting the view of the Board of Governors, Federal Reserve Bank of New York, the staff of the Federal Reserve System, or National Bureau of Economic Research.

NBER working papers are circulated for discussion and comment purposes. They have not been peer-reviewed or been subject to the review by the NBER Board of Directors that accompanies official NBER publications.

(C) 2016 by Jose Berrospide, Ricardo Correa, Linda Goldberg, and Friederike Niepmann. All rights reserved. Short sections of text, not to exceed two paragraphs, may be quoted without explicit permission provided that full credit, including $\odot$ notice, is given to the source. 
International Banking and Cross-border Effects of Regulation: Lessons from the United States Jose Berrospide, Ricardo Correa, Linda Goldberg, and Friederike Niepmann

NBER Working Paper No. 22645

September 2016

JEL No. F3,F4,G15,G21

\begin{abstract}
Domestic prudential regulation can have unintended effects across borders and may be less effective in an environment where banks operate globally. Using U.S. micro-banking data for the first quarter of 2000 through the third quarter of 2013, this study shows that some regulatory changes indeed spill over. First, a foreign country's tightening of limits on loan-to-value ratios and local currency reserve requirements increase lending growth in the United States through the U.S. branches and subsidiaries of foreign banks. Second, a foreign tightening of capital requirements shifts lending by U.S. global banks away from the country where the tightening occurs to the United States and to other countries. Third, tighter U.S. capital regulation reduces lending by large U.S. global banks to foreign residents.
\end{abstract}

Jose Berrospide

Federal Reserve Board

20 And C Streets - MS 145

Washington, DC 20551

jose.m.berrospide@frb.gov

Ricardo Correa

Board of Governors of the

Federal Reserve System

Division of International Finance

Washington DC 20551

ricardo.correa@frb.gov

\author{
Linda Goldberg \\ Federal Reserve Bank-New York \\ 33 Liberty Street \\ New York, NY 10045 \\ and NBER \\ linda.goldberg@ny.frb.org \\ Friederike Niepmann \\ Board of Governors of the \\ Federal Reserve System \\ Division of International Finance \\ Washington DC 20551 \\ friederike.niepmann@frb.gov
}




\section{Introduction}

In the period since the global financial crisis, policy discussions have highlighted the potential need for the active use of macroprudential instruments to support financial stability goals. But some macroprudential instruments might not work as intended and have effects that propagate across borders through the global linkages of international financial institutions. In the presence of cross-border banking, domestic policies might not be effective as they do not apply to the same degree to banks headquartered in foreign countries. Changes in domestic prudential instruments might also spillover into foreign markets, because domestic banks affected by the policies adjust their operations globally. ${ }^{1}$

This paper analyzes these issues focusing on the United States and attempts to answer three questions. First, do changes in foreign prudential instruments affect lending growth in the United States? Second, do U.S. global banks adjust their foreign operations when foreign prudential instruments change? Third, do U.S. regulatory changes spill over into foreign countries via U.S. global banks? We find evidence of both spillovers of foreign regulatory changes into the United States and cross-border effects of U.S. prudential instrument changes.

The United States is an interesting case, as its banking sector is markedly interconnected with the rest of the world. Foreign global banks expanded their operations in the United States in the 2000s through local branches and through separately chartered banks (Tarullo, 2012). U.S. global banks have substantial exposures to advanced economies and to emerging market countries through cross-border lending, funding, and affiliates located abroad (Cetorelli and Goldberg, 2006).

Our analysis uses regulatory reports filed by U.S. global banks and by the U.S. subsidiaries and branches of foreign banks. These bank-level data for 2000q1 through 2013q3 are combined with a database of prudential instruments newly constructed by the International Banking Research Network (IBRN) (see Cerutti, et al., 2016, for a description of the IBRN Prudential Instruments Database). The database has information on the use of 7 different prudential instruments by 64

\footnotetext{
${ }^{1}$ Lim et al. (2011), Akinci and Olmstead-Rumsey (2015), Vandenbussche et al. (2012), and Cerutti, Claessens, and Laeven (2015) analyze the effectiveness of macroprudential policies in curtailing credit growth and house price inflation using cross-country data. Cross-border spillovers of prudential policies are explored in Aiyar, Calomiris, and Wieladek (2014), Aiyar et al. (2014), and Danisewicz et al. (2015). The International Banking Research Network (IBRN) coordinated a research initiative to explore the effects of prudential instruments on the activities of global banks across borders. For an overview of the country studies and results, see Buch and Goldberg (2016).
} 
countries. Our methodology largely follows that described in Buch and Goldberg (2016) and is part of the joint research effort of the IBRN on cross-border prudential policy spillovers. ${ }^{2}$

Our first specifications test whether U.S. global banks and U.S. branches and subsidiaries of foreign banks adjust their lending in response to foreign prudential instrument changes. We find statistically significant effects for 3 instruments: capital requirements, local currency reserve requirements, and limits on loan-to-value (LTV) ratios. The tightening of prudential instruments abroad increases loan growth in the United States. Higher foreign country capital requirements abroad mainly affect U.S. loan growth through U.S. global banks, while higher local currency reserve requirements and limits on LTV ratios mainly transmit through the lending of the U.S. branches and subsidiaries of foreign banks.

Our second set of tests investigates whether U.S. global banks' exposures in foreign countries react to prudential instrument changes there. The evidence is weaker in this case. Foreign changes in prudential instruments have a weak and mostly insignificant effect on U.S. banks' claims on residents in the country where the change occurs.

Lastly, we explore whether changes in U.S. prudential instruments have effects across borders. While foreign economies have used a combination of both cyclical and structural instruments, U.S. policymakers have favored structural regulations that are less correlated with the financial cycle and are not changed frequently (Elliott, Feldberg, and Lehnert, 2013). As a result, the only U.S. instrument change recorded in the IBRN Prudential Instruments Database is related to the introduction of the Basel 2.5 capital regulations in 2013q1. Our results indicate that after this change the largest U.S. banks, those that are required to participate on annual stress tests or follow the Advanced Approaches capital framework, reduced their foreign lending growth relative to the smaller banks. ${ }^{3}$

\footnotetext{
${ }^{2}$ The following studies are part of the IBRN study on the impact of prudential instrument changes on the activities of global banks: Auer, Ganarin, and Towbin (2016); Avdjiev et al. (2016); Başkaya et al. (2016); Bonfim and Costa (2016); Bussière, Schmidt, and Vinas (2016); Caccavaio, Carpinelli, and Marinelli (2016); Damar and Mordel (2016); Frost, de Haan, and van Horen (2016); Gajewski and Krzesicki (2016); Hills et al. (2016); Ho and Wong (2016); Jara and Cabeza (2016); Levin et al. (2016); Nocciola and Żochowski (2016); Ohls, Pramor, and Tonzer (2016); Park and Lee (2016).

${ }^{3}$ More information about the Advanced Approaches capital framework can be found at this link: https://www.federalreserve.gov/bankinforeg/basel/advanced-approaches-capital-framework-implementation.htm. Information about the U.S. stress tests conducted by U.S. bank supervisors can be found at this location: https://www.federalreserve.gov/bankinforeg/stress-tests-capital-planning.htm.
} 
Taken together, and focusing on the response of U.S. global banks, our results indicate that U.S. prudential regulation reduces foreign lending, whereas tighter foreign prudential regulation increases total lending and shifts this lending away from the host countries undertaking regulatory changes. In general, the magnitudes of the identified spillovers across all the exercises appear to be small. Changes in foreign capital requirements probably had the most significant economic effect: we calculate that stricter capital requirements abroad added a total of \$249 billion in lending of U.S. global banks over the period from 2000q1 to 2013q3.

While our results are broadly consistent with the existing evidence on cross-border spillovers, there are some important differences that we have identified. The effect of higher U.S. capital requirements are consistent with Aiyar, Calomiris, Hooley, Korniyenko, and Wieladek (2014), who document that tighter capital requirements for U.K. banks decreased these banks' crossborder lending. In the U.S. data, cross-border spillovers of higher capital requirements work in both directions. Tighter capital standards abroad increased lending growth in the United States, mainly through U.S. global banks. While banks may cut lending at home and abroad to comply with higher capital standards, the change of capital requirements in one country affects the relative profitability of lending in different parts of the global banking organization. When capital requirements are higher abroad, domestic lending might become relatively more profitable compared to foreign lending through foreign subsidiaries subject to the higher capital requirements. The fact that higher local currency reserve requirements and limits on LTV ratios abroad have positive effects on U.S. lending growth follows a similar logic.

The weak response of U.S. global banks' lending to foreign policy changes in the countries where the policy changes occur is somewhat consistent with the evidence on leakages presented by Reinhardt and Sowerbutts (2015) and Aiyar, Calomiris, and Wieladek (2014), who show that foreign bank lending expands when the regulation of domestic banks tightens. While we do not find that U.S. banks expand their lending growth, we do not find them contracting their lending growth either, suggesting that foreign policy changes might not be able to impact these banks' local operations. This result contrasts with those in Temesvary (2015), who finds significant responses of U.S. banks' foreign activities to stricter bank regulation in host countries. Part of the divergence in these results may be explained by the use of different cross-country regulatory data and different methodologies for measuring the effect of changes in prudential instruments. 
A related literature with contributions by Houston, Lin, and Ma (2012) and Bremus and Fratzscher (2014) exploits a database developed by Barth, Caprio, and Levine (2013), which captures differences in bank regulation and supervision across countries, to analyze changes in global banking activities. Using information on cross-border bank flows, they find evidence for regulatory arbitrage through cross-border lending. As opposed to our paper, their tests rely on aggregate bank flows instead of bank-specific claims. In another cross-country study, Ongena, Popov, and Udell (2013) find effects of tighter home country regulation on banks’ risk taking abroad.

The next section describes the data used in the various exercises testing the transmission of prudential policies through foreign banks operating in the United States, and through U.S. global banks. Section 3 presents the empirical methodology and key empirical results. Section 4 concludes, emphasizing that despite limited real consequences for the U.S. economy over the past decade, prudential instruments applied abroad have the potential to more significantly influence U.S. loan growth in the future.

\section{Data and Stylized Facts for the United States}

Our analysis examines prudential policy spillovers internationally using four distinct bank panels. The first panel covers U.S.-headquartered global banks' total lending and varies by bank and quarter. The second dataset adds a country dimension to the bank and time dimension, capturing U.S. global banks' claims in different locations through cross-border flows or through branches or subsidiaries established in foreign markets. The two other micro-banking datasets cover foreign bank lending in the United States. One contains data on foreign-owned bank subsidiaries operating in the United States, while the other consists of data on U.S. branches of foreign banks. The data for U.S. global banks and for subsidiaries of foreign banks within the United States span the first quarter of 2000 through the third quarter of 2013, while the U.S. branches of foreign banks dataset spans the fourth quarter of 2002 through the third quarter of 2013. ${ }^{4}$

\footnotetext{
${ }^{4}$ We end the analysis in 2013q3 since the FFIEC 009 reporting form changed the next quarter. The FR Y-7Q form used in branch regressions was not introduced until 2002q4.
} 


\section{$\underline{2.1 \quad \text { Bank-level Data }}$}

Data Sources. U.S. commercial bank data cover both U.S. global banks and the U.S. subsidiaries of foreign banks. Balance sheet, income statement, and select off-balance sheet data are drawn from the Federal Financial Institutions Examinations Council (FFIEC) 031 form, better known as the Call Report. Income statement, balance sheet, and selected off-balance sheet data on U.S. bank holding companies are drawn from the FR Y-9C form. The FFIEC 009 form on the international exposures of U.S. reporting banks is the source of detailed information on the geographic distribution of U.S. bank claims on foreign residents. A bank is defined as a U.S. global bank if it reports the FFIEC 009 and is headquartered in the United States. Capital and asset data for foreign bank holding companies in our aggregated branch dataset are drawn from the FR Y-7Q form. Balance sheet and off-balance sheet data pertaining to U.S. branches and agencies of foreign banking organizations are drawn from FFIEC 002 filings, aggregated across U.S. branches to the level of the "top bank" within the global banking organization. ${ }^{5}$ National Information Center (NIC) data are used to connect commercial banks to their high holders. All of these data filings are quarterly, with the exception of the FR Y-7Q. ${ }^{6}$ Although much of the banklevel data are publicly available, bank-level data from the FFIEC 009 report are confidential. ${ }^{7}$ Further details on data sources and variable construction are in the Table A1. ${ }^{8}$

Definition of Dependent Variables. Most of the dependent variables have bank and time dimensions, with $\Delta Y_{b, t}$ defined as the change in log loans by bank $b$ at time $t$. For some specifications, these loans are divided by the location (U.S. versus foreign addressees).

For a more detailed analysis of the response of U.S. global banks' foreign lending to policy changes (outward transmission), a country $j$ dimension is added, with $\Delta Y_{b, j, t}$ defined as the

\footnotetext{
${ }^{5}$ Bank in this context includes bank holding companies and commercial banks.

${ }^{6}$ The FRY-7Q is filed quarterly by FBOs whose activities are deemed to be effectively that of a financial holding company, and is filed annually by all other FBOs. Data from the FR Y-7Q is then linearly interpolated in order to construct quarterly data for foreign BHCs.

${ }^{7}$ Most of the data collected on the FR Y-9C, FFIEC 031, FFIEC 002, and FR Y-7Q are available to the public, but there are a small number of series that are confidential.

${ }^{8}$ The data are trimmed to exclude or correct for potential reporting errors and noise. First, we identify outliers and exclude these observations from all descriptive tables and analysis. Observations are identified as outliers if they satisfy at least one of the following four criteria where applicable: 1) a change in log claims or loans $>1$ or $<-1$ (precluding most major mergers and acquisitions), 2) tier 1, illiquid asset, core deposit, or international ratio which is $>100 \%$ or $<0 \%, 3$ ) not part of a consecutive string of bank-time observations at least eight quarters in length, or 4) their home country changes between our contemporaneous and lagged periods.
} 
change in log claims extended by bank $b$ to counterparties in country $j$ at time $t .^{9}$ These claims can be cross-border, in which case they are extended from a particular location to a counterparty external to that location, or local, in which case the global bank affiliate in a location extends claims to borrowers in that location.

Bank-level Variables. As the composition of bank balance sheets may influence the effects of prudential instruments, the database also includes: bank size as captured by log of total real assets (LogTotalAssets $\left.b_{b, t-1}\right)$, percentage of a bank's portfolio of assets that is illiquid (IlliquidAssetRatio ${ }_{b, t-1}$ ), percentage of the banking organization’s balance sheet financed with core deposits $\left(\right.$ CoreDeposits $\left._{b, t-1}\right)$, percentage of banking organization's regulatory tier 1 risk-based capital to asset ratio $\left(\right.$ Tier1Ratio $\left._{b, t-1}\right)$, percentage of banking organization’s net due to minus net due from head office relative to total assets $\left(\operatorname{NetDueTF}_{b, t-1}\right)$, and percentage of international activity as proxied by the ratio of banking organization's foreign deposits plus total claims relative to total assets $\left(\right.$ InternationalRatio $\left._{b, t-1}\right) .{ }^{10}$ The analysis also utilizes information on the nationality of the foreign parent of branches and subsidiaries hosted in the United States.

Summary Statistics and Features of the U.S. Banking System. The sample of reporting banks and characteristics of balance sheet data are summarized in Table 1. The number of distinct reporting entities for each dataset is provided in the first data row. The second row reports the number of observations used in the empirical analysis, combining information on the number of entities and the number of quarters for each entity. For the outward transmission through global banks, the number of observations reflects a combination of the number of global banks active throughout our sample period and the number of countries in which each of these banks reports claims or local funding activity at each quarter.

These summary statistics provide a broad overview of the credit activities of the financial institutions captured in our empirical analysis. In general, the United States is a financial center, both hosting the offices of several foreign financial institutions and serving as the headquarters

\footnotetext{
${ }^{9}$ The terms "claims" includes loans and securities holdings of banks.

${ }^{10}$ Total assets are converted to 2012q1 dollars using GDP deflator data from the U.S. Bureau of Economic Analysis.
} 
location for a group of large global banks. The U.S. offices of foreign banks, branches, and subsidiaries account for 18 to 23 percent of U.S. bank assets in our sample period, with their loans representing between 12 and 17 percent of total loans in the United States. The largest foreign participants in the U.S. banking sector are headquartered in advanced economies, particularly in Europe.

Similarly, U.S. global banks have a notable presence in foreign markets. Foreign claims, which are composed of cross-border claims and claims originated at foreign offices, for the U.S. global banks in our sample average about 9 percent of total assets. Total claims increased from 8 to 10 percent of total assets, on average, between 2002 and 2012. Most of this increase is accounted for by growth in affiliate local claims, which rose from 2 to 5 percent of total assets during that period (cross border claims dropped slightly from 6 to 5 percent). By country of destination, between 2002 and 2012 total claims to advanced foreign economies went up from 4 to 7 percent and those to emerging market economies decreased from 4 to 3 percent. The U.S. branches and subsidiaries of foreign banks have higher U.S. lending growth rates, on average, compared with U.S. global banks. Variability in lending is highest for the U.S. branches of foreign banks. For U.S. global banks, the growth in foreign claims by bank and by location is more volatile than lending domestically.

\subsection{Data on Prudential Instruments}

The prudential instruments included in the IBRN Prudential Instruments Database (Cerutti et al., 2016) are: capital requirements, sector specific capital buffers, limits on LTV ratios, concentration ratios, reserve requirements (local currency and foreign currency), and interbank exposure limits. Although the full database covers 64 countries, the only policies that enter into our regression analysis are from those countries with banking entities in the United States or spanned by the claims of U.S. global banks. For inward analysis through global banks, the prudential instruments are weighted aggregates across countries, with weights constructed on the basis of bank-specific information on country exposures in each period.

For regression analysis of policy spillovers to yield convincing findings, the specific prudential instruments used in each regression must have a sufficient level of variation. We screen for sufficient variation by examining the counts of changes in each prudential instrument as relevant for the particular banking entities in each data subset, the number of countries associated with 
those changes, and the number of tightening and loosening observations. The panels of Table 2 show this information for the four datasets. While there is not a well-defined rule available for determining a sufficient degree of variation for regressors in an econometric specification, we apply a judgmental approach to capture a sufficient number of episodes and number of countries. As a result of this screening we exclude concentration ratios in our outward and inward transmission analysis for U.S. global banks, and exclude foreign reserve requirements, interbank exposure limits, and concentration ratios from our inward transmission analysis for U.S. branches of foreign banks.

\subsection{Data on country business and financial cycles}

The analysis introduces controls for country business cycles and credit cycles. These controls are not only important to account for credit demand conditions, but also for assessment of whether the effects of the prudential instruments vary over the cycle. Details on the construction of the business cycle control (output gap) and the financial cycle control (credit-to-GDP gap) are described in Bank for International Settlements (2014) and Drehmann, Borio, and Tsatsaronis (2011), respectively.

\section{Empirical Method and Regression Results}

This section provides conceptual observations on how changes in prudential instruments might spill over internationally into lending activity, presents the main empirical specifications, and reports results for the analysis on the impact of prudential regulations on bank claims both in the United States and abroad. Section 3.1 focuses on the spillovers of foreign regulatory changes to U.S. lending. Section 3.2 explores the effect of changes in foreign regulations on the activities of U.S. global banks in foreign locations. It also analyzes the response of U.S. global banks’ foreign activities when U.S. capital requirements change.

While more extensively discussed in Buch and Goldberg (2016), changes in capital requirements, reserve requirements, and loan-to-value ratios could spill over to bank lending through various channels that depend on the institutions examined. Consider first a change in capital requirements abroad. U.S. global banks that operate foreign subsidiaries need to finance their foreign assets with subsidiary-specific capital. When foreign capital requirements are tightened, U.S. parent banks may cut lending in these markets and employ the available funding 
for lending in a different location. In contrast, the direction of effects of tighter capital requirements in foreign banks' home countries on their U.S. subsidiaries is less clear. On the one hand, tighter capital requirements in the foreign bank's home country imply that the bank must finance its balance sheet with more capital on a consolidated basis. To achieve this, the parent bank may reduce lending both at home and abroad. However, tighter capital requirements at home also mean that the relative costs of lending at home and abroad change, with lending abroad becoming relatively less expensive.

As opposed to the stand-alone structure of subsidiaries, the assets in branches of foreign banks are directly linked to parent banks' balance sheets. A reduction of lending in the U.S. branches should thus have the same effect on the parent bank's tier 1 ratio as a reduction of lending in its home offices. One would therefore expect that higher capital requirements at home lead to a reduction in lending by U.S. branches of foreign banks, as the parent bank seeks to comply with higher capital standards.

Local currency reserve requirements used as prudential tools are put in place by national monetary authorities to control the growth in domestic credit. Higher reserve requirements imply that banks need to hold a larger fraction of funds as reserves with the central bank and can lend out only a smaller fraction to local borrowers. Reserve requirements in local currency, however, do not constrain the bank's activities in other countries. Since local funding becomes more expensive, banks have an incentive to raise funding abroad and could move operations to other locations. They could do this both by increasing lending of their foreign branches or their foreign subsidiaries.

Limits on LTV ratios are aimed at reducing credit in the economy and often are specifically targeted at counteracting a potential real estate bubble. Such limits apply to all banks that engage in mortgage lending in a given country by decreasing the pool of eligible borrowers. A tightening of LTV limits should thus decrease the local lending opportunities for all banks and might induce a shift in lending to other markets.

Within regression specifications, the exact mechanisms through which adjustments occur are not constrained by instrument and type of entities considered. Some policy instruments affect all banks that operate in a given market, as is the case of loan-to-value ratios. Other instruments may differentially affect banks in relation to their mode of servicing a location, as could be the case 
with capital requirements, or the structure of their balance sheets in the case of reserve requirements.

\subsection{Inward Analysis: Spillovers into the United States from Foreign Prudential Policies}

The inward transmission analysis investigates the consequences for lending in the United States of foreign prudential policies through two channels. First, U.S. banks with large foreign activities might respond to changes in regulation abroad by reallocating activity across foreign and domestic locations. Second, foreign banks that have to comply with home country regulation might adjust lending by their U.S. subsidiaries or U.S. branches. ${ }^{11}$

\section{Specifications}

We run regressions separately for (i) U.S. global banks, (ii) U.S. subsidiaries of foreign banks, and (iii) U.S. branches of foreign banks. In each specification, we regress the log change in lending $\Delta Y_{b, t}$ by entity $b$ in quarter $t$ on a relevant measure of foreign prudential policy changes, including several lagged bank characteristics $X_{b, t-1}$ (see Section 2.1 for details) as well as bankand quarter-fixed effects. We also control for financial and business cycle variables. Effectively, these regressions show whether policy changes abroad had an effect on lending growth by entity $b$, after controlling for a bank-specific time-invariant component in entity $b$ 's lending growth and a quarter-specific shift in lending growth common to all entities in the sample.

We estimate the following equation on the sample of 59 U.S.-headquartered banks with sizeable exposures in foreign countries (global banks):

$\Delta Y_{b, t}=\alpha_{0}+\sum_{k=0}^{2} \alpha_{k+1} \operatorname{Exp}_{b, t-k}+a_{4} X_{b, t-1}+\alpha_{5} Z_{b, t}+f_{b}+f_{t}+\epsilon_{b, t}$.

where $\operatorname{Exp}_{b, t-k}$ stands for the foreign-exposure-weighted index and captures the extent to which

policies are tightened or loosened in countries where entity $b$ has exposures in quarter $t-k{ }^{12}$ To

\footnotetext{
${ }^{11}$ U.S. credit could also be affected through foreign banks that do not have U.S. affiliates but lend cross-border to U.S. firms.

${ }^{12}$ The exposure weighted prudential index for bank $b$ at time $t$ is calculated using this formula:

$\operatorname{ExpP}_{b, t}=\sum_{j \neq U S A} P P_{j t} \cdot \varphi_{j b, t-1}$, where $\cdot \varphi_{j b, t-1}=\frac{\sum_{t=t-4}^{t-1} \text { claims }_{b j t}}{\sum_{j \neq U S A} \sum_{t=t-4}^{t-1} \text { claims }_{b j t}}$
} 
control for foreign country financial and economic developments, the regression also controls for exposure-weighted credit-to-GDP and output gap variables $Z_{b, t}{ }^{13}$ Different prudential policies are explored using this specification and for this bank panel. Prudential policy effects can be immediate $(k=0)$ or appear over the next two quarters $(k=1,2)$. Standard errors are robust.

The regression equation for the 102 U.S. subsidiaries of foreign banks and 137 U.S. branches of foreign banks is given by:

$\Delta Y_{b, j, t}=\alpha_{0}+\sum_{k=0}^{2} \alpha_{k+1} H_{o m e P} P_{j, t-k}+\alpha_{4} X_{b, t-1}+\alpha_{5} Z_{j, t}+f_{b}+f_{t}+\epsilon_{b, j, t}$.

where $H o m e P_{j, t-k}$ indicates whether regulation tightened or loosened in home country $j$ of entity $b$ in quarter $t-k . Z_{j, t}$ includes country-specific measures of the home country's credit-to-GDP gap and output gap. Standard errors are clustered at the country level.

\section{Spillovers into the United States}

Table 3 presents the results of the inward transmission through U.S. global banks, U.S. subsidiaries of foreign banks, and U.S. branches of foreign banks. We only display results for those prudential instruments for which we find significant effects for at least one of these three types of entities. The table presents estimates of contemporaneous and two periods of lagged effects. It also displays tests of the sum of effects, with the presentation columns organized both by instrument and entity type. Three instruments show significant inward spillovers: capital requirements, local currency reserve requirements and LTV limits. Tighter foreign capital requirements increase the lending of U.S. global banks and of U.S. subsidiaries of foreign banks (the evidence for subsidiaries is weaker though), but do not significantly affect lending by the U.S. branches of foreign banks. In contrast, tighter foreign limits on LTV ratios and local currency reserve requirements cause U.S. subsidiaries and branches of foreign banks to increase their lending. We do not find significant effects on lending of foreign changes in sector specific capital buffers. The PruC index, which aggregates prudential policy changes over all instruments, has largely insignificant effects, probably because the consequences for lending

$P P_{j t}$ in the formula above stands for any of the indices that measure the change in one of the prudential instruments (e.g. limits on LTV ratios, capital requirements etc.) by regulators across all countries spanned by $j$. claims ${ }_{b j t}$ represent bank $b$ 's claims on country $j$ at time $t$ through the FFIEC 009 reports.

${ }^{13}$ The exposure-weighted cycle variables are constructed in parallel to the exposure-weighted prudential index. For details see footnote 12 . 
growth vary substantially by prudential instrument and are more appropriately evaluated in isolation. $^{14}$

Interestingly, both bank-specific characteristics and country conditions drive quarterly lending growth rates. Lending growth by U.S. affiliates of foreign banks follows home country financial and economic conditions. In particular lending growth by U.S. subsidiaries is relatively strong when the home country has slower growth, while lending growth by U.S. branches is stronger when the credit-to-GDP gap is higher in the home country (implying a larger gap between the credit-to-GDP ratio and its long-term trend). In contrast, the negative and significant coefficients on the exposure-weighted credit-to-GDP gap indicate that the lending growth of U.S. global banks is lower when the credit-to-GDP gap in the countries where these banks operate is higher. This is likely because these banks refocus their lending towards foreign countries away from domestic lending when foreign demand for credit is strong, a hypothesis that is supported by the positive coefficient on the credit-to-GDP gap in the outward exercise.

Bank-level characteristics also help explain lending growth. After controlling for bank fixed effects on lending growth, U.S. global banks with higher tier 1 ratios (in the previous quarter) have stronger lending growth. This also holds for their foreign activities as shown later in the outward exercise and is consistent with previous results in the literature. ${ }^{15}$ Tier 1 capital ratios do not appear as drivers of foreign-owned bank lending growth in the United States. Instead, lending growth is stronger when illiquid asset ratios are lower.

Below we discuss the regression results of Table 3 in more detail and evaluate the economic impact on loan growth in the U.S. from changes in capital requirements, local currency reserve requirements, and limits on LTV ratios abroad.

\section{Capital Requirements}

The conjecture that foreign capital requirements could shift global bank activity away from the host country is supported by the regression results. We find a significant positive effect of tighter

\footnotetext{
${ }^{14}$ The effects of changes in concentration ratios were not analyzed because of limited variation in foreign policies in all three samples. For the same reason, the effects of changes in exposure limits and foreign reserve requirements were not explored for U.S. affiliates of foreign banks.

${ }^{15}$ See, e.g., Bernanke and Lown (1991) and Berrospide and Edge (2010).
} 
capital requirements abroad on total lending by U.S. global banks (see column 1 of Table 3). ${ }^{16}$ We also used as the dependent variable total lending minus loans to foreign banks, C\&I loans to foreign addressees, and loans to foreign governments and official institutions. Results based on these alternative dependent variables show that the effects on lending growth are not limited to U.S. lending. U.S. banks increase domestic and third-country lending growth in response to higher foreign capital requirements. ${ }^{17}$

With regards to the lending of foreign-owned subsidiaries, the regression results indicate that our substitution effect from tighter home capital requirements (lending abroad becomes relatively less expensive compared with home lending) can dominate the effect associated with the consolidated entity's increased capital needs and give parent banks a net incentive to expand subsidiary operations in the United States. However, overall the support for this effect is relatively weak: the estimated coefficient shown in column 2 is significant only at the 11 percent level. The point estimate related to branch lending is not significant at conventional levels (see column 3).

How large is the positive effect on loan growth from tighter capital requirements abroad? If there were a change in capital requirements in all countries in which a U.S. bank holds claims, then that bank's lending growth would be 3.6 percentage points higher according to the estimated coefficient in column 1. This corresponds to around 38 percent of one standard deviation of the dependent variable. The average value of the exposure-weighted index is 0.028 in the sample, implying an average positive effect on a bank’s lending growth rate of 0.1 percentage point.

We conduct a basic experiment to illustrate the magnitudes of potential spillovers from past capital requirement changes: (i) we calculate the effect on a bank's lending growth in each quarter multiplying the capital requirement index in each period with the estimated coefficient; (ii) we convert the effect on the bank's lending growth rate to a U.S. dollar value taking into account the lending volume of the bank in the previous period; and (iii) we aggregate the calculated U.S. dollar value over all banks. It is important to note that the estimated coefficients

\footnotetext{
${ }^{16}$ Lagged values of the capital requirement index are dropped in the regressions displayed in columns 1 to 3 , since these were never significant.

${ }^{17}$ Detailed estimates are shown in Table A2. As noted later, the outward analysis shows that U.S. banks do not increase lending growth in the countries where capital requirements are changed.
} 
often have large confidence intervals, so the resulting dollar amounts are rough estimates of potential spillover effects.

Most of the regulatory changes in the sample occurred in the first quarter of 2012 and 2013 when several industrialized countries introduced Basel II.5 and Basel III, respectively. In some of these countries, U.S. banks have large operations, for example, in Canada, Hong Kong and Switzerland. Accordingly, the effect on aggregate lending of U.S. global banks is notable. Based on our calculations, the introduction of Basel II.5 or Basel III in 2012q1 in 28 countries led U.S. global banks to increase lending by around 2.4 percentage points ( $\$ 119$ billion). Summed over all quarters, additional lending due to changes in capital requirements abroad totaled \$249 billion.

\section{Local Currency Reserve Requirements}

The conjecture that higher local reserve requirements in the home country will make operations by foreign-owned affiliates in the U.S. relatively more attractive is supported by the regression results, as can be seen in column 5 of Table 3. Higher local reserve requirements in the home country increase a U.S. subsidiary's lending growth rate by a total of 5 percentage points over half a year (beta coefficient of 0.07). The contemporaneous and lagged coefficients in the branch regression (column 6 of Table 3) are not jointly significant at standard levels but there is some weak evidence that branch lending responds as well since the coefficient on the contemporaneous prudential variable is significant at the 11 percent level. Banks should not prefer to move activity to subsidiaries or to branches in particular, since the impact of local reserve requirements is not related to the bank's organizational structure as discussed earlier.

U.S. global banks do not seem to respond at all to local reserve requirement changes abroad. In principle, changes in local reserve requirements in a market could also affect U.S. global banks that operate there. However, U.S. global banks do not fund themselves to a significant extent in foreign/local currencies and are probably little affected by these types of regulatory changes.

We investigated whether banks respond symmetrically to tightening versus loosening reserve requirements. In terms of magnitudes, the effects appear to be similar but the timing of responses differs. The effect of a tightening unfolds immediately, while responses to a loosening of reserve requirements occur with a lag of half a year. 
Figure 1 illustrates the aggregate effects of reserve requirement changes abroad on lending by U.S. subsidiaries of foreign banks following the methodology described earlier. The largest effect occurred in 2012. On 18 January 2012, the ECB lowered the reserve requirement ratio from 2 percent to 1 percent. India and China, which were parent countries for U.S. subsidiaries in 2012, also lowered their local reserve requirements in this year. Summing the U.S. dollar changes in lending from 2012q1 to 2012q3 over subsidiaries suggests that the reduction in local reserve requirements in this period led to roughly $\$ 7$ billion lower lending by these entities, a bit less than half a percent of their total lending over the same period.

\section{Limits on Loan-to-value Ratios}

The regression results in columns 8 and 9 of Table 3 support the conjecture that banks headquartered abroad redirect activity to the United States in response to tightened LTV limits in their home counties. Lending by both U.S. branches and subsidiaries of foreign banks expands in response to these changes. ${ }^{18}$

If tightening occurs in the parent country, lending growth by U.S. subsidiaries and U.S. branches of foreign banks increases by 2.2 and 2.7 percentage points, respectively, based on estimates in columns 8 and 9 (sum of contemporaneous and lagged coefficients). Figure 2 shows the aggregate effects of past changes in LTV limits by quarter. The volatility of aggregate effects over time is mainly a reflection of tightening and loosening in foreign countries. For subsidiaries, the switching signs on the contemporaneous versus lagged effects of policy changes (see column 8) also play a role. Most changes in LTV limits occurred after the 2007-2008 financial crisis in advanced economies like Sweden, Canada, Norway and the Netherlands but also in developing countries like China and Brazil. Summing the effects of past LTV changes over the sample period and over both types of entities suggests that U.S. branches and subsidiaries lent out an additional \$15 billion from 2003q3 to 2013q3 due to policy changes in their home countries.

Subsidiaries contributed around 45 percent, branches around 55 percent to the increase. ${ }^{19}$ Overall

\footnotetext{
${ }^{18}$ We did not find evidence for differential effects of tightening versus loosening LTV limits.

${ }^{19}$ The larger contribution of branches to this expansion stems from a larger impact of an LTV ratio change on branch lending, compared to subsidiary lending, and the fact that more local reserve requirement changes occurred in the home countries of U.S. branches.
} 
the additional lending over the sample period is small, reflecting a tiny fraction of these entities' total lending (0.04 percent). ${ }^{20}$

3.2 Outward Analysis: International response of U.S. global banks to U.S. and foreign prudential policies

The outward transmission exercise assesses the effects of foreign prudential policies on the growth of U.S. banks' claims to foreign countries, including on the reallocation of U.S. banks' external claims across foreign markets. The analysis also explores the impact of U.S regulation on U.S. banks’ claims abroad.

\section{Impact of foreign prudential instruments on U.S. banks' foreign claims}

First we consider the impact of different prudential instruments used by the destination country on U.S. bank claims abroad. Each of the prudential instrument measures enters the regression specification with its contemporaneous value and two lags. Formally, we estimate the regression equation:

$\Delta Y_{b, j, t}=\alpha_{0}+\left(\alpha_{1} \operatorname{DestP}_{j, t}+\alpha_{2} \operatorname{Dest}_{j, t-1}+\alpha_{3} \operatorname{Dest}_{j, t-2}\right)+\alpha_{4} X_{b, t-1}+\alpha_{5} Z_{j, t}+f_{j}+$

$f_{t}+f_{b}+\varepsilon_{b, j, t}$

where the prudential instrument changes are captured by $\operatorname{Dest}_{j, t}$, which records the changes in the prudential instruments of country $j$ in which U.S. bank $b$ has exposures at time $t$. The dependent variable is the change in logs of U.S. bank $b$ 's claims on country $j$ at time $t$ evaluated on an ultimate risk basis.

Table 4 summarizes the main results for individual prudential instruments on the foreign claim growth of U.S. banks. Only two prudential instruments have some statistically significant coefficients: LTV ratio limits and interbank exposure limits. However, the sum of coefficients on these two measures for all lags is not significant, suggesting only a weak effect of prudential regulation in the destination countries on U.S. bank foreign claims. The weak results have two interpretations. First, while some of these policies have been actively used across U.S. counterparty countries, especially in emerging markets, exposures of U.S. global banks to

\footnotetext{
${ }^{20}$ In 2013q3, total lending of branches in our dataset was $\$ 518$ billion versus $\$ 595$ billion for subsidiaries.
} 
emerging markets are smaller than exposures to advanced economies; it may be that global banks just choose to absorb the costs of the extra regulation. Alternatively, it may be that these policies are ineffective in changing the growth of foreign claims at U.S. banks.

Among other drivers of total claim growth of U.S. global banks, the financial cycle variable has the expected signs in most cases though the effects seem to be economically small. The negative and significant coefficient on the international ratio suggests that the foreign claim growth is smaller for more diversified banks (banks with more international activities). Core deposits are negatively related to total claims growth, reflecting the fact that U.S. banks with smaller shares of core deposits on their balance sheets (and thus more dependent on wholesale funding) lend more to foreign residents. The positive and significant coefficient on both the illiquid asset ratio and the net due to ratio suggest that less liquid banks and banks with more net internal borrowing from their parents exhibit a higher growth rate in their foreign claims.

\section{Impact of U.S. prudential instruments on U.S. banks' foreign claims}

Second, we test for the impact of changes in U.S. prudential instruments on U.S. banks' foreign claims. The use of prudential instruments in the United States between 2000 and 2013 are essentially related to the stricter regulation mandated by the Dodd-Frank Act and the Basel standards on capital regulation, in particular the Basel II.5 standards implemented in January 2013 and the Basel III standards that became effective in January 2014. These regulatory changes are captured in the IBRN Prudential Instruments Database in the capital requirements index. Since our sample ends in 2013q3, only the implementation of Basel II.5 can be captured in our empirical analysis. Given this setting, we use the cumulative change in the capital requirement index for the United States as the variable of interest. This indicator is equal to one from the first quarter in 2013 until the end of the sample, and zero otherwise. This approach makes the empirical test a de facto difference-in-difference estimation. More formally, we use the following regression specification:

$$
\begin{aligned}
& \Delta Y_{b, j, t}=\alpha_{0}+\alpha_{1} U S_{-} C u m_{-} \text {CapReq } q_{t}+\alpha_{2} X_{b, t-1}+\alpha_{3} U S_{-} \text {Cum_CapReq } \\
& f_{j}+f_{b}+\varepsilon_{b, j, t}
\end{aligned}
$$

where the prudential instrument is captured by US_Cum_CapReq, which records the cumulative changes in U.S. capital requirements. We also include interaction terms between this instrument 
and some bank characteristics in vector $X_{b, t-1}$ to complete the difference-in-difference analysis. As before, the dependent variable is the change in logs of U.S. bank b's claims on country $j$ at time $t$ evaluated on an ultimate risk basis. In this specification, the U.S. prudential instrument varies only by time and thus we only include bank and country fixed effects. We also use specifications that include country-time fixed effects to account for loan demand at the country level. In these cases, US_Cum_CapReq is absorbed by the country-time fixed effect and thus we focus our attention only on the interaction of US_Cum_CapReq $t_{t}$ and bank-specific characteristics.

Most of the recent regulatory changes in the United States have focused on the systemic global banks which are subject to the Federal Reserve's stress tests, known as the Comprehensive Capital Analysis and Review (CCAR) and, among these banks, those that follow the so-called Advanced Approach capital rules. ${ }^{21}$ Therefore, we test for a differential impact of the stricter U.S. regulation on the growth in total and cross-border claims for CCAR/non-CCAR and Advanced Approach/non-Advanced Approach banks. To this end, we include interactions between US_Cum_CapReq and dummy variables that take the value of one for CCAR or Advanced Approach banks and zero otherwise. We expect that if there is any negative effect of the new capital regulations on the growth in foreign bank claims, it should be significant for the group of large global banks. ${ }^{22}$

This expectation is supported by the results presented in Table 5. The first four columns of the table examine the changes in total claims and cross-border claims to all countries. Columns 5 through 8 examine the changes in cross-border claims to advanced foreign and emerging economies. In almost all cases, the interaction of US_Cum_CapReq CCAR and Advanced Approach banks are negative and significant, which confirms that the new Basel capital regulations reduced the growth in foreign claims at the largest U.S. banks subject to the Federal Reserve stress tests compared to smaller institutions not subject to these stress tests. For example, taking into account that the difference in growth rates between CCAR and nonCCAR banks before 2013 was on average 0.4 percentage points (the growth rate was 1 percent

\footnotetext{
${ }^{21}$ CCAR BHCs are generally global U.S. BHCs with total consolidated assets above $\$ 50$ billion. As of 2013q3, there were 30 CCAR BHCs, 23 of which had foreign claims in the 59 countries in our sample. Advanced Approach BHCs are CCAR BHCs with total assets above \$250 billion and foreign exposures larger than \$10 billion.

${ }^{22}$ Our estimates likely provide a lower bound to the total effects of regulatory changes as the banks may have adapted their portfolios as early as 2011.
} 
for CCAR banks and 0.6 percent for non-CCAR banks), our estimates indicate that the difference in growth rates between the two groups of banks and across the two periods should have been 5.5 percentage points lower for CCAR banks (the difference-in-difference estimate). The growth rate differential observed in the data is -5.2 percentage points. Thus, most of the reduction in the growth rate of CCAR banks relative to non-CCAR banks could be attributable to the change in U.S. capital regulation following the implementation of Basel II.5.

We explore further whether the negative impact of the stricter capital regulation is influenced by bank-specific characteristics. To that end, we include interaction terms between the cumulative capital requirements index and three bank-specific characteristics: size, the tier 1 capital ratio, and the core deposits to total liabilities ratio. ${ }^{23}$ Table 6 shows the regression results. The estimations in the first two columns include US_Cum_CapReqt as a standalone variable and separate country, time, and bank fixed effects. The change in U.S. capital regulation seems to reduce the growth in foreign claim of U.S. global banks, as suggested by the negative coefficient on US_Cum_CapReqt, but this effect is not statistically significant. However, balance sheet characteristics appear important to bank reactions to the change in capital requirements. For example, as indicated by the three significant interaction terms between US_Cum_CapReq ${ }_{t}$ and size, tier 1 capital ratio, and the core deposit to total liabilities ratio in column 2, the negative impact of the stricter regulation is stronger for larger banks. In contrast, banks with more capital (tier 1 capital ratio) and core deposits are able to increase their claims after the new regulations are implemented. Column 3 shows that the significance of the interaction terms between US_Cum_CapReqt and size and core deposits is robust to accounting for the foreign demand for credit through country-time fixed effects.

To better control for the effect of bank size, and to verify that the impact of the new regulations on foreign claims occurs mainly through the largest global banks, we estimate the same specifications splitting our sample by CCAR and non-CCAR banks, and by Advanced Approach and non-Advanced Approach banks. These results are shown in columns 4 through 7. As expected, the coefficients on the interaction terms are mostly significant for CCAR and Advanced-Approach banks. The interaction terms with core deposits for Advanced-Approach

\footnotetext{
${ }^{23}$ These three interaction terms have the only significant coefficients in the specifications that include interactions between the cumulative changes in the U.S. capital requirements and all bank characteristics.
} 
banks, and with both tier 1 capital and the core deposits ratio for CCAR banks are positive and significant, indicating that large banks with more regulatory capital and core deposits are able to offset the impact of the stricter capital regulation. Recent evidence shows that large U.S. banks subject to the stress tests have been increasing their regulatory capital and their deposits base (International Monetary Fund, 2015). Our results indicate that this trend may help them withstand the tougher regulations.

Our results are consistent with previous findings in the literature suggesting a reduction in crossborder activities caused by stricter prudential policies (e.g. Aiyar, et al., 2014). This is especially the case for the largest global banks subject to higher capital requirements that apply to the consolidated entity.

\section{Concluding Remarks}

The 2007-2008 financial crisis has led many countries around the world to review their use of microprudential and macroprudential policy instruments. In a financially integrated world in which banks are global and run large cross-border operations, two questions naturally arise. First, have prudential policies taken by national regulators affected risk taking and credit growth beyond national borders? Second, can domestic prudential policies be effective in containing rapid domestic credit growth and addressing excessive risk taking? The U.S. experience is useful since the country is home to a number of globally active banks, many of which are systemically important, and simultaneously hosts many foreign banks engaged in lending in the United States through both subsidiaries and branches. We focus primarily on the response of credit growth through these banking entities.

We find clear evidence that lending in the United States is affected by foreign policy changes. A tightening of foreign prudential instruments leads to an increase in U.S. lending by both domestically-owned global banks with significant foreign operations and by the U.S. affiliates of foreign banks. Specifically, lending growth rises with tighter foreign capital requirements, limits on LTV ratios, and local currency reserve requirements enacted in foreign economies. The capacity of foreign and U.S. global banks to lend appears to shift, at least in part, from the foreign countries, where it is being constrained, to the United States. 
We also find that the largest U.S. global banks, those that are deemed systemic and thus have been required to finance a larger proportion of their balance sheets with capital, appear to cut credit abroad relatively more than the smaller banks in response to tighter capital requirements in the United States. Although the intent of these capital requirements was not to reduce the supply of credit, the short-term effect points to lower foreign claims growth as a result of the stricter requirements. In contrast, we find that the use of prudential instruments by foreign authorities does not have a significant impact on the activities of U.S. banks in those foreign countries.

While the international spillovers from past prudential policy tightening were moderate, our results highlight the challenges that policy makers face today. Effective control of domestic credit can be complicated by the prudential policies implemented in foreign jurisdictions. At the same time, calibration of domestic policies will need to take into account the spillovers of prudential policy changes in foreign countries and their cross-border effects. Despite limited real consequences for the U.S. economy over the past decade, prudential instruments applied abroad have the potential to more significantly influence loan growth in the future through a variety of banking channels. 


\section{References}

Aiyar, Shekhar, Charles W. Calomiris, John Hooley, Yevgeniya Korniyenko, and Tomasz Wieladek. 2014. “The international transmission of bank capital requirements: Evidence from the UK,” Journal of Financial Economics, 113(3), 368-382.

Aiyar, Shekhar, Charles W. Calomiris, Tomasz Wieladek. 2014. “Does Macro-Prudential Regulation Leak? Evidence from a UK Policy Experiment,” Journal of Money, Credit and Banking 46 (s1), 181-214.

Akinci, Ozge and Jane Olmstead-Rumsey. 2015. "How Effective are Macroprudential Policies? An Empirical Investigation,” Federal Reserve Board International Finance Discussion Papers 2015-1136 (May).

Auer, Simone, Maja Ganarin and Pascal Towbin. 2016. “International Banking and Cross-border Effects of Regulation: Lessons from Switzerland.” Manuscript.

Avdjiev, Stefan, Cathérine Koch, Patrick McGuire, and Goetz von Peter. 2016. “International Prudential Policy Spillovers: A Global Perspective.” Manuscript.

Bank for International Settlements. 2014. 84th Annual Report, "Debt and the financial cycle: domestic and global", Chapter IV, June.

Barth, James R., Gerard Caprio Jr, and Ross Levine. 2013. "Bank regulation and supervision in 180 countries from 1999 to 2011," Journal of Financial Economic Policy 5(2), 111-219.

Başkaya, Yusuf Soner, Mahir Binici, Şebnem Kalemli-Özcan, and Turalay Kenç. 2016. “International Banking and Cross-Border Effects of Regulation: Lessons from Turkey”.

Bernanke, Ben and Cara S Lown. 1991. “The Credit Crunch”, Brookings Papers on Economic Activity, 22 (2), 205-248.

Berrospide, Jose M., and Rochelle M. Edge. 2010. "The Effects of Bank Capital on Lending: What do we Know, and What does it Mean?" International Journal of Central Banking, 6 (4) 554.

Bonfim, Diana and Sónia Costa. 2016. “International Banking and Cross-border effects of regulation: Lessons from Portugal.” Manuscript. . 
Bremus, Franziska and Marcel Fratzscher. 2014. "Drivers of Structural Change in Cross-Border Banking Since the Global Financial Crisis,” Deutsches Institut fur Wirtschaftsforschung discussion papers 1411.

Buch, Claudia and Linda S. Goldberg. 2016. “Cross-Border Prudential Policy Spillovers: How Much? How Important? Evidence from the International Banking Research Network.” Manuscript.

Bussière, Matthieu, Julia Schmidt and Frédéric Vinas. 2016. “International Banking and CrossBorder Effects of Regulation: Lessons from France.” Manuscript.

Caccavaio, Marianna, Luisa Carpinelli and Giuseppe Marinelli. 2016. “International Banking and Cross-border Effects of Regulation: Lessons from Italy.” Manuscript.

Cerutti, Eugenio, Stijn Claessens, and Luc Laeven. 2015. “The use and effectiveness of macroprudential policies: New evidence,” Journal of Financial Stability (November).

Cerutti, Eugenio, Ricardo Correa, Elisabetta Fiorentino, and Esther Segalla. 2016. “Changes in Prudential Policy Instruments-A New Cross Country Database.” Manuscript.

Cetorelli, Nicola and Linda Goldberg. 2006. “Risks in U.S. Bank International Exposure,” Federal Reserve Bank of New York Staff Reports No. 240.

Cetorelli, Nicola and Linda Goldberg. 2012. "Banking Globalization and Monetary Transmission,” Journal of Finance 67(5), 1811-1843.

Cetorelli, Nicola and Linda Goldberg. 2016. “Organizational Complexity and Liquidity Management in Global Banks,” NBER working paper 22169 (April).

Damar, H. Evren and Adi Mordel. 2016. “International Banking and Cross-Border Effects of Regulation: Lessons from Canada.” Manuscript.

Danisewicz, P, Dennis Reinhardt, and Rhiannon Sowerbutts. 2015. “On a tight leash: does bank organizational structure matter for macroprudential spillovers?” Bank of England Working Paper 524.

Drehmann, Mathias, Claudio Borio, and Kostas Tsatsaronis. 2011. "Anchoring countercyclical capital buffers: The role of credit aggregates," International Journal of Central Banking 7(4), 189-240. 
Elliott, Douglas J., Greg Feldberg, and Andreas Lehnert. 2013. “The History of Cyclical Macroprudential Policy in the United States," Finance and Economics Discussion Series No. 2013-29.

Fischer, Stanley. 2015. "Macroprudential Policy in the U.S. Economy,” speech delivered at the “Macroprudential Monetary Policy" $59^{\text {th }}$ Economic Conference of the Federal Reserve Bank of Boston, Boston, Massachusetts, October 2.

Frost, Jon, Jakob de Haan and Neeltje van Horen. 2016. "International Banking and Cross-border effects of regulation: Lessons from the Netherlands.” Manuscript.

Gajewski, Krzysztof and Oskar Krzesicki. 2016. "International Banking and Cross-border Effects of Regulation: Lessons from Poland.” Manuscript.

Hills, Robert, Dennis Reinhardt, Rhiannon Sowerbutts, and Tomasz Wieladek. 2016. “Crossborder Regulatory Spillovers: How Much? How Important? What Sectors? Lessons from the United Kingdom.” Manuscript.

Ho, Kelvin and Eric Wong. 2016. "International Banking and Cross-border effects of regulation: Lessons from Hong Kong.” Manuscript.

Houston, Joel F., Chen Lin, Yue Ma. 2012. "Regulatory Arbitrage and International Bank Flows,” Journal of Finance 67 (5), 1845-1895.

International Monetary Fund. 2015. "United States—Financial Sector Assessment Program: Stress Testing-Technical Note,” IMF Country Report No. 15/173. July.

Jara, Alejandro and Luis Cabeza. 2016. "International Banking and Cross-border Effects of Regulation: Lessons from Chile.” Manuscript.

Levin, Gabriel, Calixto Lopez, Fabrizio Lopez-Gallo, and Serafin Martinez. 2016. "International Banking and Cross-border effects of regulation: Lessons from Mexico.” Manuscript.

Lim, Cheng H., Francesco Columba, Alejo Costa, Piyabha Kongsamut, Akira Otani, Mustafa Saiyid, Torsten Wezel, and Xiaoyong Wu. 2011. "Macroprudential Policy: What Instruments and How Are They Used? Lessons from Country Experiences,” IMF Working Paper 11/238. 
Nocciola, Luca and Dawid Żochowski. 2016. "International Banking and Cross-border Effects of Prudential Regulation: Lessons from the Euro Area.” Manuscript.

Ohls, Jana, Marcus Pramor and Lena Tonzer. 2016. “International Banking and Cross-Border Effects of Regulation: Lessons from Germany.” Manuscript.

Ongena, Steven, Alexander Popov, and Gregory F. Udell. 2013. "When the cat's away the mice will play: Does regulation at home affect bank risk-taking abroad?” Journal of Financial Economics 108 (3), 727-750.

Park, Hyunggeun, Jungyeoun Lee. 2016. “International Banking and Cross-border effects of regulation: Lessons from Korea.” Manuscript.

Tarullo, Daniel K. 2012. "Regulation of Foreign Banking Organizations,” speech delivered at the Yale School of Management Leaders Forum, New Haven, Connecticut, November 28.

Tarullo, Daniel K. 2015. “Advancing Macroprudential Policy Objectives,” speech delivered at the Office of Financial Research and Financial Stability Oversight Council's $4^{\text {th }}$ Annual Conference on Evaluating Macroprudential Tools: Complementarities and Conflicts, Arlington, Virginia, January 30.

Temesvary, Judit. 2015. “The Role of Regulatory Arbitrage in U.S. Banks’ International Lending Flows: Bank-level Evidence.” Working Paper, Hamilton College.

Vandenbussche, Jerome, Ursula Vogel, and Enrica Detragiache, 2015. “Macroprudential Policies and Housing Prices: A New Database and Empirical Evidence for Central, Eastern, and Southeastern Europe,” Journal of Money, Credit and Banking 47(1), 343-377. 


\section{Figure 1: Home country local currency reserve requirements and lending by U.S.}

\section{subsidiaries of foreign banks}

The chart shows the effect of changes in home country local currency reserve requirements on lending by U.S. subsidiaries of foreign banks. Calculations follow the methodology described in the text and are based on the estimated coefficients shown in column 5 of Table 3. The figure plots by date the additional lending by subsidiaries in U.S. dollar values due to observed changes in local currency reserve requirements in these entities' home countries.

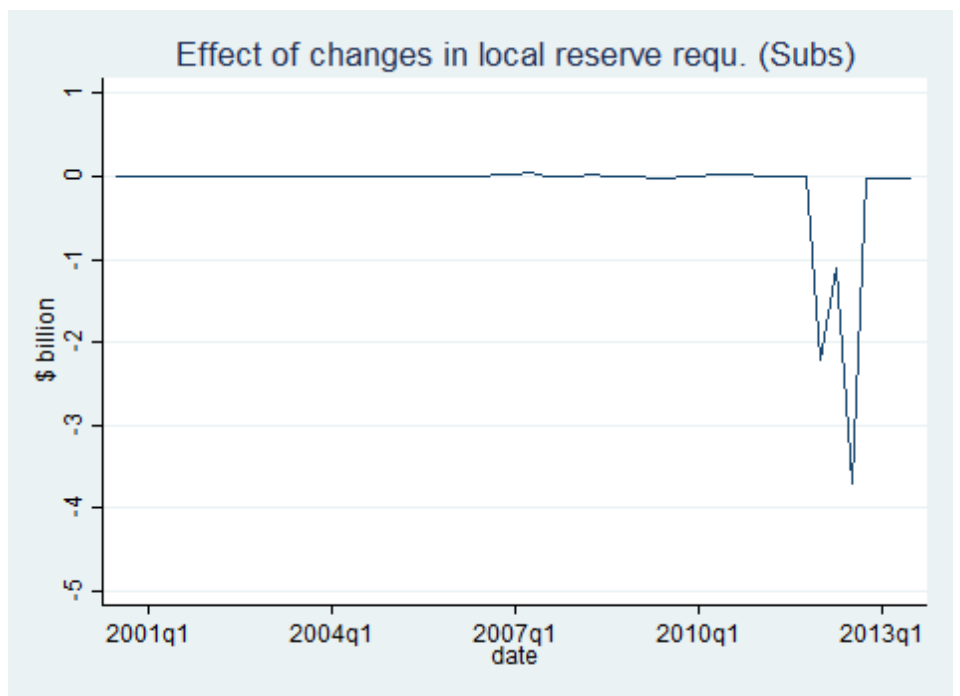

\section{Figure 2: Home country limits on LTV ratios and lending by U.S. subsidiaries and branches of foreign banks}

The chart shows the effect of changes in home country limits on LTV ratios on lending by U.S. subsidiaries (dashed line) and branches (solid line) of foreign banks. Calculations follow the methodology described in the text and are based on the estimated coefficients shown in column 8 and 9 of Table 3. The figure plots by date the additional lending by subsidiaries and branches in U.S. dollar values due to observed changes in limits on LTV ratios in these entities' home countries.

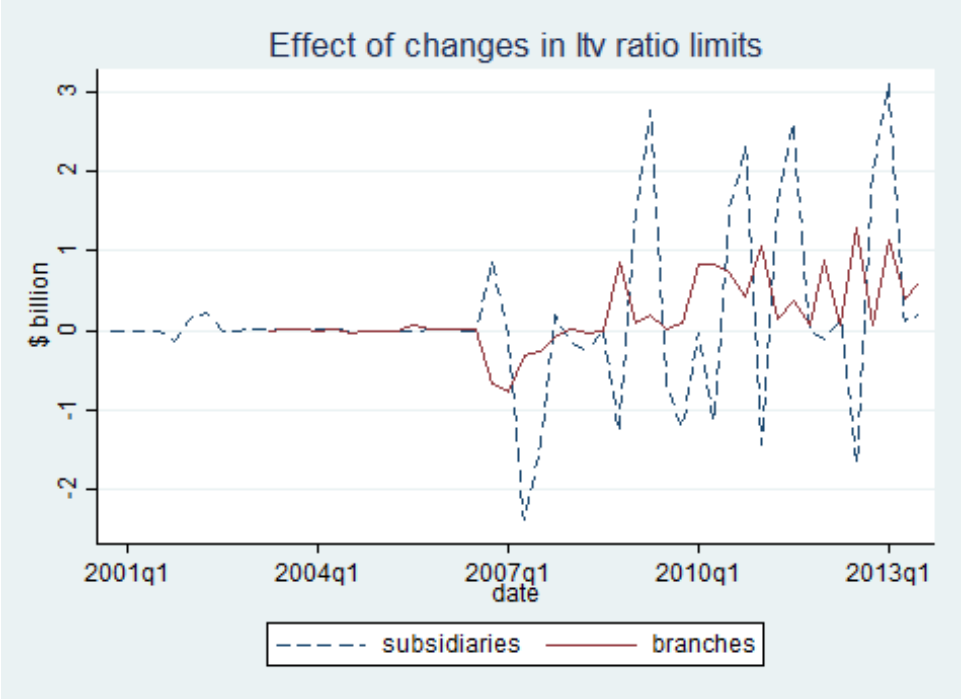




\section{Table 1: Summary Statistics on Bank Lending and Characteristics}

This table provides summary statistics for bank balance sheet and lending data, summarizing those observations included in our baseline regressions. Data are observed quarterly from 2000q1-2013q3 for U.S. global banks and U.S. subsidiaries of foreign banks, and from 2002q4-2013q3 for U.S. branches of foreign banks. Banking data sources by subset can be found in Table A1 and are reported at the level of the top bank within the global banking organization for U.S. global banks and for the U.S. branches of foreign banks (aggregated across U.S. branches in this case), and at the subsidiary level for the U.S. subsidiaries of foreign banks. The tier 1 asset ratio reported for branches is that of this associated parent. The Net Due To (or Due From) variable measures from the perspective of a bank's head office total net internal lending (or borrowing) vis-à-vis all its related domestic and international offices. Cycle variables in the Inward US Global Bank sample are constructed as exposure-weighted averages.

\begin{tabular}{|c|c|c|c|c|c|c|c|c|c|c|c|c|}
\hline & \multicolumn{3}{|c|}{$\begin{array}{c}\text { Outward- US Global } \\
\text { Banks } \\
\end{array}$} & \multicolumn{3}{|c|}{$\begin{array}{c}\text { Inward- US Global } \\
\text { Banks } \\
\end{array}$} & \multicolumn{3}{|c|}{$\begin{array}{c}\text { Inward- US Subsidiaries of } \\
\text { Foreign Banks }\end{array}$} & \multicolumn{3}{|c|}{$\begin{array}{c}\text { Inward- US Branches of } \\
\text { Foreign Banks } \\
\end{array}$} \\
\hline Entity Count & \multicolumn{3}{|c|}{59} & \multicolumn{3}{|c|}{59} & \multicolumn{3}{|c|}{102} & \multicolumn{3}{|c|}{137} \\
\hline Observation Count & \multicolumn{3}{|c|}{35,483} & \multicolumn{3}{|c|}{1,873} & \multicolumn{3}{|c|}{2,801} & \multicolumn{3}{|c|}{4,262} \\
\hline Variable & Mean & Median & SD & Mean & Median & SD & Mean & Median & SD & Mean & Median & SD \\
\hline \multicolumn{13}{|c|}{ Balance sheet data (for each bank $b$ and quarter $t$ [and destination country $j$ for Outward claims]) } \\
\hline \multicolumn{13}{|l|}{ Dependent Variables } \\
\hline$\Delta$ Log Loans (Claims) $)^{25}$ & 0.010 & 0 & 0.311 & 0.008 & 0.008 & 0.095 & 0.023 & 0.016 & 0.098 & 0.019 & 0.005 & 0.208 \\
\hline$\Delta$ Log Cross-Border Claims & 0.007 & 0 & 0.335 & & & & & & & & & \\
\hline$\Delta$ Log Local Claims & 0.011 & 0 & 0.411 & & & & & & & & & \\
\hline \multicolumn{13}{|l|}{ Balance Sheet Composition } \\
\hline Total Assets (Billions) & 633.2 & 197.8 & 763.3 & 269.8 & 66.1 & 519.8 & 14.5 & 1.3 & 30.9 & 15.8 & 3.6 & 26.4 \\
\hline Tier1 Ratio (\%) & 11.2 & 10.5 & 3.4 & 11.8 & 10.9 & 4.1 & 16.8 & 12.6 & 12.5 & 10.4 & 9.5 & 4.8 \\
\hline Illiquid Assets Ratio (\%) & 57.3 & 60.7 & 21.9 & 64.0 & 72.9 & 21.9 & 70.3 & 74.9 & 17.7 & 39.6 & 36.2 & 28.1 \\
\hline International Activity & 11.5 & 5.0 & 13.8 & 18.6 & 8.6 & 21.5 & & & & & & \\
\hline $\begin{array}{l}\text { Net Due To (Head } \\
\text { Office)/Assets (\%) }\end{array}$ & 0.1 & 0.0 & 0.7 & -0.5 & 0.0 & 6.4 & 2.8 & 0.0 & 8.2 & 8.0 & 11.0 & 46.8 \\
\hline Core Deposits Ratio (\%) & 39.7 & 40.0 & 23.0 & 50.5 & 55.4 & 21.2 & 60.8 & 66.1 & 24.6 & 6.0 & 0.9 & 12.2 \\
\hline \multicolumn{13}{|l|}{ Cycle Variables } \\
\hline BIS Financial Cycle & 3.0 & 3.0 & 16.0 & 1.8 & 0.9 & 5.4 & 1.4 & 0.6 & 15.2 & 3.6 & 3.5 & 15.3 \\
\hline BIS Business Cycle & -0.1 & -0.1 & 2.1 & -0.1 & 0.0 & 1.3 & 0.0 & -0.1 & 1.5 & 0.0 & 0.0 & 1.8 \\
\hline
\end{tabular}

\footnotetext{
${ }^{25}$ Due to data availability, loans are used in all Inward regressions while claims are utilized in all Outward regressions. Claims, Cross-Border Claims, and Local Claims have a country dimension in the Outward regression sample.
} 
Table 2: Summary Statistics on Changes in the Prudential Instruments

These tables show summary statistics on changes in the prudential instruments in home and/or destination countries of banks located in the U.S. over the period 2000q1-2013q3. Data on the seven instruments come from the prudential instruments database compiled by Cerutti et al. (2016) and are on the quarter level. The table is based on the estimation sample. The table shows the total number of changes, i.e. tightening or loosening, for each instrument as well as the proportion of non-zero entries. All home and/or destination countries of banks located in the U.S. are included. Source: IBRN.

\begin{tabular}{|c|c|c|c|c|c|c|}
\hline \multirow[b]{2}{*}{ Instrument } & \multicolumn{5}{|c|}{ Base Data (Before Aggregating to Exposure-Weighted Measures) } & \multirow{2}{*}{$\begin{array}{c}\begin{array}{c}\text { Exposure-Weighted } \\
\text { Observations }\end{array} \\
\text { Proportion ExpP_t } \\
\text { Nonzero }\end{array}$} \\
\hline & $\begin{array}{c}\text { \# of } \\
\text { Country- } \\
\text { Time } \\
\text { Changes } \\
\end{array}$ & $\begin{array}{l}\text { \# of Country- } \\
\text { Time Changes } \\
\text { (Tightening) }\end{array}$ & $\begin{array}{c}\text { \# of Country- } \\
\text { Time } \\
\text { Changes } \\
\text { (Loosening) } \\
\end{array}$ & $\begin{array}{l}\text { \# of Bank- } \\
\text { Time } \\
\text { Changes }\end{array}$ & $\begin{array}{c}\text { Proportion } \\
\text { Base-MPP } \\
\text { Nonzero }\end{array}$ & \\
\hline \multicolumn{7}{|l|}{ Outward- US Global Banks } \\
\hline Prudential Index & 502 & 329 & 173 & 1400 & 0.17 & 0.89 \\
\hline General capital requirements & 64 & 64 & 0 & 258 & 0.03 & 0.24 \\
\hline Sector specific capital buffer & 69 & 51 & 18 & 545 & 0.02 & 0.39 \\
\hline Loan-to-value ratio limits & 88 & 64 & 24 & 689 & 0.04 & 0.16 \\
\hline $\begin{array}{l}\text { Reserve requirements: } \\
\text { Foreign }\end{array}$ & 133 & 83 & 50 & 809 & 0.04 & 0.19 \\
\hline Reserve requirements: Local & 269 & 124 & 145 & 1112 & 0.08 & 0.48 \\
\hline Interbank exposure limit & 22 & 21 & 1 & 209 & 0.01 & 0.21 \\
\hline Concentration ratio & 32 & 30 & 2 & 356 & 0.01 & 0.32 \\
\hline \multicolumn{7}{|l|}{ Inward- US Global Banks } \\
\hline Prudential Index & 506 & 333 & 173 & 1469 & 0.16 & 0.69 \\
\hline General capital requirements & 64 & 64 & 0 & 307 & 0.03 & 0.15 \\
\hline Sector specific capital buffer & 68 & 51 & 17 & 622 & 0.02 & 0.28 \\
\hline Loan-to-value ratio limits & 88 & 64 & 24 & 833 & 0.03 & 0.37 \\
\hline $\begin{array}{l}\text { Reserve requirements: } \\
\text { Foreign }\end{array}$ & 136 & 86 & 50 & 932 & 0.04 & 0.43 \\
\hline Reserve requirements: Local & 270 & 125 & 145 & 1224 & 0.07 & 0.55 \\
\hline Interbank exposure limit & 22 & 21 & 1 & 260 & 0.01 & 0.11 \\
\hline Concentration ratio & 32 & 30 & 2 & 404 & 0.01 & 0.18 \\
\hline \multicolumn{7}{|c|}{ Inward- US Subsidiaries of Foreign Banks } \\
\hline Prudential Index & 95 & 74 & 21 & 213 & 0.08 & \\
\hline General capital requirements & 22 & 22 & 0 & 55 & 0.02 & \\
\hline Sector specific capital buffer & 17 & 14 & 3 & 28 & 0.01 & \\
\hline Loan-to-value ratio limits & 31 & 23 & 8 & 93 & 0.03 & \\
\hline $\begin{array}{l}\text { Reserve requirements: } \\
\text { Foreign }\end{array}$ & 1 & 1 & 0 & 1 & 0.00 & \\
\hline Reserve requirements: Local & 31 & 14 & 17 & 39 & 0.01 & \\
\hline Interbank exposure limit & 10 & 10 & 0 & 18 & 0.01 & \\
\hline Concentration ratio & 6 & 6 & 0 & 10 & 0.00 & \\
\hline \multicolumn{7}{|c|}{ Inward- US Branches of Foreign Banks } \\
\hline Prudential Index & 227 & 176 & 51 & 653 & 0.15 & \\
\hline General capital requirements & 37 & 37 & 0 & 128 & 0.03 & \\
\hline Sector specific capital buffer & 36 & 28 & 8 & 89 & 0.02 & \\
\hline Loan-to-value ratio limits & 58 & 47 & 11 & 219 & 0.05 & \\
\hline $\begin{array}{l}\text { Reserve requirements: } \\
\text { Foreign }\end{array}$ & 48 & 35 & 13 & 79 & 0.02 & \\
\hline Reserve requirements: Local & 99 & 56 & 43 & 237 & 0.06 & \\
\hline Interbank exposure limit & 14 & 14 & 0 & 48 & 0.01 & \\
\hline Concentration ratio & 17 & 17 & 0 & 41 & 0.01 & \\
\hline
\end{tabular}




\section{Table 3: Inward Specification}

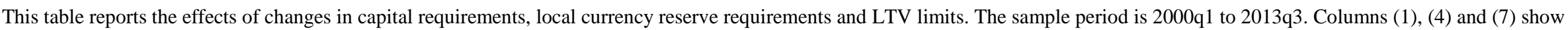

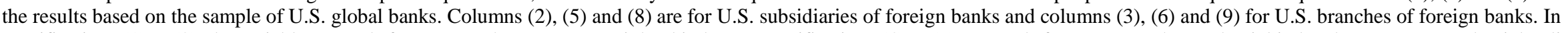

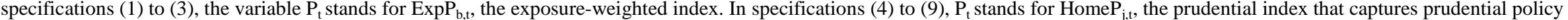

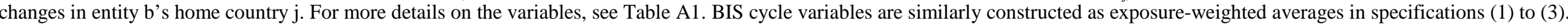

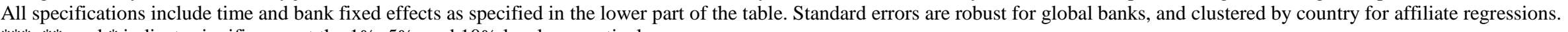
$* * *, * *$, and * indicate significance at the $1 \%, 5 \%$, and $10 \%$ level, respectively.

\begin{tabular}{|c|c|c|c|c|c|c|c|c|c|}
\hline & \multicolumn{3}{|c|}{ Capital requirements } & \multicolumn{3}{|c|}{ Reserve Requirements Local } & \multicolumn{3}{|c|}{ Loan to Value Ratio } \\
\hline & (1) & $(2)$ & (3) & (4) & (5) & (6) & (7) & (8) & (9) \\
\hline & Global banks & Subs & Branches & Global banks & Subs & Branches & Global banks & Subs & Branches \\
\hline \multirow[t]{2}{*}{ P_t } & $0.036 * *$ & 0.016 & -0.013 & -0.003 & $0.016^{* *}$ & 0.024 & 0.043 & -0.013 & $0.018 * *$ \\
\hline & $(0.018)$ & $(0.009)$ & $(0.023)$ & $(0.008)$ & $(0.007)$ & $(0.014)$ & $(0.031)$ & $(0.009)$ & $(0.009)$ \\
\hline \multirow[t]{2}{*}{ P_t-1 } & & & & 0.009 & 0.008 & -0.009 & -0.001 & 0.014 & 0.002 \\
\hline & & & & $(0.008)$ & $(0.007)$ & $(0.019)$ & $(0.011)$ & $(0.014)$ & $(0.011)$ \\
\hline \multirow[t]{2}{*}{ P_t-2 } & & & & -0.005 & $0.026 * * *$ & 0.008 & -0.010 & $0.021 * *$ & 0.007 \\
\hline & & & & $(0.007)$ & $(0.004)$ & $(0.010)$ & $(0.010)$ & $(0.010)$ & $(0.014)$ \\
\hline \multirow[t]{2}{*}{ Log Total Assets_t-1 } & $-0.066 * * *$ & $-0.039 * * *$ & -0.018 & $-0.067 * * *$ & $-0.040 * * *$ & -0.018 & $-0.067 * * *$ & $-0.040 * * *$ & -0.018 \\
\hline & $(0.015)$ & $(0.009)$ & $(0.013)$ & $(0.015)$ & (0.009) & $(0.013)$ & $(0.015)$ & (0.009) & $(0.013)$ \\
\hline \multirow[t]{2}{*}{ Tier1 Ratio_t-1 } & $0.002 * *$ & 0.000 & -0.000 & $0.002 * *$ & 0.000 & -0.000 & $0.002 * *$ & 0.000 & -0.000 \\
\hline & $(0.001)$ & $(0.001)$ & $(0.001)$ & $(0.001)$ & $(0.001)$ & $(0.001)$ & $(0.001)$ & $(0.001)$ & $(0.001)$ \\
\hline \multirow[t]{2}{*}{ Illiquid Assets Ratio_t-1 } & -0.000 & $-0.001 * * *$ & $-0.002 * * *$ & -0.000 & $-0.001 * * *$ & $-0.002 * * *$ & -0.000 & $-0.001 * * *$ & $-0.002 * * *$ \\
\hline & $(0.000)$ & $(0.000)$ & $(0.000)$ & $(0.000)$ & $(0.000)$ & $(0.000)$ & $(0.000)$ & $(0.000)$ & $(0.000)$ \\
\hline \multirow[t]{2}{*}{ Net Due To_t-1 } & -0.003 & 0.000 & -0.000 & -0.003 & 0.000 & -0.000 & -0.003 & 0.000 & -0.000 \\
\hline & $(0.003)$ & $(0.001)$ & $(0.000)$ & $(0.003)$ & $(0.001)$ & $(0.000)$ & $(0.003)$ & $(0.001)$ & $(0.000)$ \\
\hline \multirow[t]{2}{*}{ Core Deposits Ratio_t-1 } & 0.001 & -0.000 & 0.000 & 0.001 & -0.000 & 0.000 & 0.001 & -0.000 & 0.000 \\
\hline & $(0.000)$ & $(0.000)$ & $(0.001)$ & $(0.000)$ & $(0.000)$ & $(0.001)$ & $(0.000)$ & $(0.000)$ & $(0.001)$ \\
\hline \multirow[t]{2}{*}{ BIS financial cycle_t } & $-0.001 * *$ & $0.001 *$ & $0.001^{* * *}$ & $-0.001 * *$ & $0.001^{*}$ & $0.001 * * *$ & $-0.001 * *$ & $0.001^{*}$ & $0.001^{* * *}$ \\
\hline & $(0.000)$ & $(0.000)$ & $(0.000)$ & $(0.000)$ & $(0.000)$ & $(0.000)$ & $(0.000)$ & $(0.000)$ & $(0.000)$ \\
\hline \multirow[t]{2}{*}{ BIS business cycle_t } & 0.000 & $0.005^{* * *}$ & 0.002 & 0.000 & $0.005^{* * *}$ & 0.002 & 0.000 & $0.005^{* * *}$ & 0.001 \\
\hline & $(0.003)$ & $(0.002)$ & $(0.004)$ & $(0.003)$ & $(0.002)$ & $(0.003)$ & $(0.003)$ & $(0.002)$ & $(0.004)$ \\
\hline \multirow[t]{2}{*}{ International Activity_t-1 } & $0.001^{*}$ & & & $0.001^{*}$ & & & $0.001^{*}$ & & \\
\hline & $(0.001)$ & & & $(0.001)$ & & & $(0.001)$ & & \\
\hline Observations & 1,873 & 2,801 & 4,262 & 1,873 & 2,801 & 4,262 & 1,873 & 2,801 & 4,262 \\
\hline R-Squared & 0.196 & 0.191 & 0.100 & 0.195 & 0.193 & 0.100 & 0.197 & 0.193 & 0.100 \\
\hline Adjusted R-Squared & 0.141 & 0.142 & 0.059 & 0.140 & 0.143 & 0.059 & 0.141 & 0.143 & 0.059 \\
\hline Number of banks & 59 & 102 & 137 & 59 & 102 & 137 & 59 & 102 & 137 \\
\hline Proportion of P_t Nonzero & 0.145 & 0.020 & 0.030 & 0.549 & 0.014 & 0.056 & 0.370 & 0.033 & 0.051 \\
\hline P_t Coefficient Sum & & & & 0.001 & $0.050 * * *$ & 0.023 & 0.031 & 0.022 & $0.027 *$ \\
\hline$p$-value & & & & [0.914] & {$[0.000]$} & {$[0.246]$} & {$[0.270]$} & [0.263] & [0.067] \\
\hline
\end{tabular}




\section{Table 4: Outward transmission of Destination Country Prudential Policy}

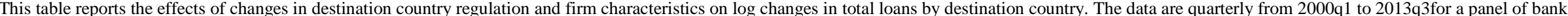

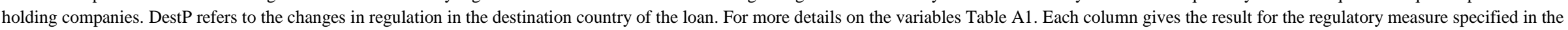
column headline. All specifications include fixed effects as specified in the lower part of the table. Standard errors are clustered by country. ${ }^{* * *}$, **, and * indicate significance at the $1 \%$, $5 \%$, and $10 \%$ level, respectively.

\begin{tabular}{|c|c|c|c|c|c|c|c|}
\hline & (1) & (2) & (3) & (4) & (5) & (6) & (7) \\
\hline & $\begin{array}{l}\text { Prudential } \\
\text { IndexC }\end{array}$ & $\begin{array}{c}\text { Capital } \\
\text { Requirements }\end{array}$ & $\begin{array}{l}\text { Sector- } \\
\text { Specific } \\
\text { Capital } \\
\text { Buffer } \\
\end{array}$ & $\begin{array}{c}\text { Loan To } \\
\text { Value Ratio }\end{array}$ & $\begin{array}{c}\text { Reserve } \\
\text { Requirement } \\
\text { Foreign }\end{array}$ & $\begin{array}{c}\text { Reserve } \\
\text { Requirement } \\
\text { Local }\end{array}$ & $\begin{array}{c}\text { Interbank } \\
\text { Exposure Limits }\end{array}$ \\
\hline \multirow[t]{2}{*}{ P_t } & 0.005 & -0.008 & -0.002 & 0.012 & -0.005 & 0.006 & -0.002 \\
\hline & $(0.006)$ & $(0.014)$ & $(0.010)$ & $(0.010)$ & $(0.005)$ & $(0.009)$ & $(0.018)$ \\
\hline \multirow[t]{2}{*}{ P_t-1 } & 0.007 & -0.009 & -0.003 & $-0.015^{*}$ & 0.001 & 0.011 & $-0.037 * *$ \\
\hline & $(0.005)$ & (0.013) & $(0.009)$ & (0.009) & $(0.011)$ & $(0.008)$ & $(0.018)$ \\
\hline \multirow[t]{2}{*}{ P_t-2 } & $0.009 *$ & -0.014 & 0.013 & $0.016^{*}$ & 0.002 & 0.007 & 0.013 \\
\hline & $(0.005)$ & $(0.011)$ & $(0.014)$ & $(0.010)$ & $(0.005)$ & $(0.006)$ & $(0.012)$ \\
\hline \multirow[t]{2}{*}{ Log Total Assets_t-1 } & -0.006 & -0.006 & -0.006 & -0.006 & -0.006 & -0.006 & -0.006 \\
\hline & $(0.007)$ & $(0.008)$ & $(0.008)$ & $(0.008)$ & $(0.008)$ & $(0.007)$ & $(0.008)$ \\
\hline \multirow[t]{2}{*}{ Tier1 Ratio_t-1 } & 0.001 & 0.001 & 0.001 & 0.001 & 0.001 & 0.001 & 0.001 \\
\hline & $(0.001)$ & $(0.001)$ & $(0.001)$ & $(0.001)$ & $(0.001)$ & $(0.001)$ & $(0.001)$ \\
\hline \multirow[t]{2}{*}{ Illiquid Assets Ratio_t-1 } & $0.001^{* *}$ & $0.001^{* *}$ & $0.001^{* *}$ & $0.001^{* *}$ & $0.001^{* *}$ & $0.001^{* *}$ & $0.001^{* *}$ \\
\hline & $(0.000)$ & $(0.000)$ & $(0.000)$ & $(0.000)$ & $(0.000)$ & $(0.000)$ & $(0.000)$ \\
\hline \multirow[t]{2}{*}{ International Activity_t-1 } & $-0.002 * * *$ & $-0.002 * * *$ & $-0.002 * * *$ & $-0.002 * * *$ & $-0.002 * * *$ & $-0.002 * * *$ & $-0.002 * * *$ \\
\hline & $(0.001)$ & $(0.001)$ & $(0.001)$ & $(0.001)$ & $(0.001)$ & $(0.001)$ & $(0.001)$ \\
\hline \multirow[t]{2}{*}{ Net Due To_t-1 } & $0.002 *$ & $0.002 *$ & $0.002 *$ & $0.002^{*}$ & $0.002^{*}$ & $0.002 *$ & $0.002 *$ \\
\hline & $(0.001)$ & $(0.001)$ & $(0.001)$ & $(0.001)$ & $(0.001)$ & $(0.001)$ & $(0.001)$ \\
\hline \multirow[t]{2}{*}{ Core Deposits Ratio_t-1 } & $-0.001 * * *$ & $-0.001 * * *$ & $-0.001 * * *$ & $-0.001 * * *$ & $-0.001 * * *$ & $-0.001 * * *$ & $-0.001 * * *$ \\
\hline & $(0.000)$ & $(0.000)$ & $(0.000)$ & $(0.000)$ & $(0.000)$ & $(0.000)$ & $(0.000)$ \\
\hline \multirow[t]{2}{*}{ BIS financial cycle_t } & $0.000 * *$ & $0.000 * *$ & $0.000 * *$ & $0.000 * *$ & $0.000 * *$ & $0.000 * *$ & $0.000 * *$ \\
\hline & $(0.000)$ & $(0.000)$ & $(0.000)$ & $(0.000)$ & $(0.000)$ & $(0.000)$ & $(0.000)$ \\
\hline \multirow[t]{2}{*}{ BIS business cycle_t } & 0.003 & 0.004 & 0.004 & 0.004 & 0.004 & 0.004 & 0.004 \\
\hline & $(0.002)$ & $(0.002)$ & $(0.003)$ & $(0.003)$ & $(0.003)$ & $(0.003)$ & $(0.002)$ \\
\hline Observations & 25986 & 25986 & 25986 & 25986 & 25986 & 25986 & 25986 \\
\hline Adjusted R-squared & 0.016 & 0.016 & 0.016 & 0.016 & 0.016 & 0.016 & 0.016 \\
\hline $\operatorname{DestP}_{(t)}$ coefficient sum & $0.021 *$ & -0.030 & 0.008 & 0.013 & -0.002 & 0.023 & -0.026 \\
\hline p-value & {$[0.091]$} & {$[0.266]$} & [0.669] & [0.243] & {$[0.917]$} & {$[0.150]$} & [0.427] \\
\hline
\end{tabular}




\section{Table 5: Impact of Changes in U.S. Capital Regulation on Foreign Claim Growth by Type of Claim and Destination Country}

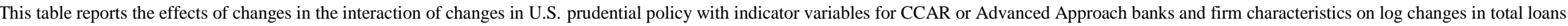

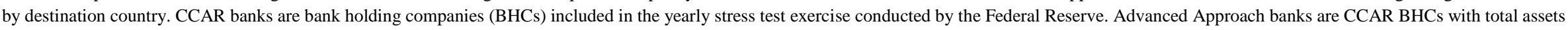

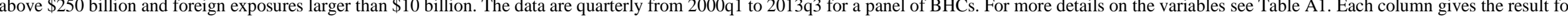

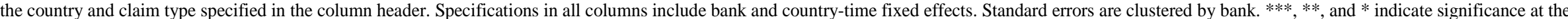
$1 \%$, $5 \%$, and $10 \%$ level, respectively

\begin{tabular}{|c|c|c|c|c|c|c|c|c|}
\hline & \multicolumn{4}{|c|}{ All Countries } & \multicolumn{2}{|c|}{ Advanced Foreign Countries } & \multicolumn{2}{|c|}{ Emerging Markets } \\
\hline & $(1)$ & $(2)$ & (3) & $(4)$ & $(5)$ & $(6)$ & $(7)$ & $(8)$ \\
\hline & \multicolumn{2}{|c|}{ Total Claims } & \multicolumn{2}{|c|}{ Cross-Border Claims } & \multicolumn{2}{|c|}{ Cross-Border Claims } & \multicolumn{2}{|c|}{ Cross-Border Claims } \\
\hline \multirow{2}{*}{$\begin{array}{l}\text { US_Cum_CapReq_t x } \\
\text { CCAR_t }\end{array}$} & $-0.055^{* * *}$ & & $-0.074^{* * *}$ & & $-0.078 * *$ & & $-0.072 * * *$ & \\
\hline & $(0.012)$ & & $(0.018)$ & & $(0.033)$ & & $(0.019)$ & \\
\hline \multirow[t]{2}{*}{$\begin{array}{l}\text { US_Cum_CapReq_t x } \\
\text { Advanced Approach_t }\end{array}$} & & $-0.048^{* * *}$ & & $-0.046^{* *}$ & & -0.042 & & $-0.053 * *$ \\
\hline & & $(0.014)$ & & $(0.019)$ & & $(0.028)$ & & $(0.020)$ \\
\hline \multirow[t]{2}{*}{ Log Total Assets_t-1 } & -0.006 & -0.003 & -0.007 & -0.004 & -0.014 & -0.012 & 0.003 & 0.005 \\
\hline & $(0.011)$ & $(0.011)$ & $(0.011)$ & $(0.011)$ & $(0.015)$ & $(0.015)$ & $(0.016)$ & $(0.016)$ \\
\hline \multirow[t]{2}{*}{ Tier1 Ratio_t-1 } & $0.003^{* *}$ & $0.003^{* * *}$ & $0.003^{* *}$ & $0.003 * *$ & $0.005^{* * *}$ & $0.005 * *$ & 0.001 & 0.001 \\
\hline & $(0.001)$ & $(0.001)$ & $(0.001)$ & $(0.001)$ & $(0.002)$ & $(0.002)$ & $(0.002)$ & $(0.002)$ \\
\hline \multirow[t]{2}{*}{ Illiquid Assets Ratio_t-1 } & $0.001^{*}$ & $0.001^{*}$ & 0.001 & 0.001 & $0.002 * *$ & $0.002 * *$ & .0001 & .0001 \\
\hline & $(0.000)$ & $(0.000)$ & $(0.001)$ & $(0.001)$ & $(0.001)$ & $(0.001)$ & $(0.001)$ & $(0.001)$ \\
\hline \multirow[t]{2}{*}{ International Activity_t-1 } & $-0.002 * * *$ & $-0.002 * * *$ & $-0.002 * * *$ & $-0.002 * * *$ & $-0.003 * * *$ & $-0.003^{* * *}$ & $-0.001^{*}$ & $-0.001 *$ \\
\hline & $(0.001)$ & $(0.001)$ & $(0.000)$ & $(0.000)$ & $(0.001)$ & $(0.001)$ & $(0.001)$ & $(0.001)$ \\
\hline \multirow[t]{2}{*}{ Net Due To_t-1 } & 0.002 & 0.002 & 0.002 & 0.002 & 0.003 & 0.003 & 0.005 & 0.005 \\
\hline & $(0.002)$ & $(0.002)$ & $(0.003)$ & $(0.003)$ & $(0.002)$ & $(0.002)$ & $(0.019)$ & $(0.019)$ \\
\hline \multirow[t]{2}{*}{ Core Deposits Ratio_t-1 } & -.0003 & -.0004 & -0.001 & -0.001 & $-0.001 *$ & $-0.002 *$ & -.0004 & -0.001 \\
\hline & $(0.001)$ & $(0.001)$ & $(0.001)$ & $(0.001)$ & $(0.001)$ & $(0.001)$ & $(0.001)$ & $(0.001)$ \\
\hline Observations & 35,483 & 35,483 & 31,114 & 31,114 & 14,809 & 14,809 & 16,305 & 16,305 \\
\hline R-Squared & 0.12 & 0.12 & 0.13 & 0.13 & 0.1 & 0.1 & 0.15 & 0.15 \\
\hline Country-time FE & Yes & Yes & Yes & Yes & Yes & Yes & Yes & Yes \\
\hline
\end{tabular}




\section{Table 6: Impact of Changes in U.S. Capital Regulation on Total Foreign Claim Growth}

This table reports the effects of changes in U.S. prudential policy, the interaction of changes in U.S. prudential policy with changes in destination country regulation, and firm characteristics on log changes in total loans by destination country. The data are quarterly from 2000q1 to 2013q3 for a panel of bank holding companies. For more details on the variables see Table A1. Each column gives the result for the subset of banks specified in the column header. CCAR banks are BHCs included in the yearly stress test exercise conducted by the Federal Reserve. Adv. Approach banks are CCAR BHCs with total assets above $\$ 250$ billion and foreign exposures larger than $\$ 10$ billion. Specifications in all columns include bank fixed effects, with the first two columns including country fixed effects. Country-time fixed effects are used as indicated in the lower part of the table. Standard errors are clustered by bank. ${ }^{* * *},{ }^{* *}$, and * indicate significance at the $1 \%, 5 \%$, and $10 \%$ level, respectively.

\begin{tabular}{|c|c|c|c|c|c|c|c|}
\hline & $(1)$ & All Banks & (3) & $\begin{array}{c}\text { CCAR } \\
\text { Banks } \\
(5) \\
\end{array}$ & $\begin{array}{c}\text { Non- } \\
\text { CCAR } \\
\text { Banks } \\
\\
(6)\end{array}$ & $\begin{array}{c}\text { Adv. } \\
\text { Approach } \\
\text { Banks } \\
(7) \\
\end{array}$ & $\begin{array}{c}\text { Non- } \\
\text { Adv. } \\
\text { Approach } \\
\text { Banks } \\
(8)\end{array}$ \\
\hline US_Cum_CapReq_t & $\begin{array}{l}-0.005 \\
(0.009)\end{array}$ & $\begin{array}{c}0.057 \\
(0.082)\end{array}$ & & & & & \\
\hline $\begin{array}{l}\text { US_Cum_CapReq_t } \\
\text { Log Total Assets_t-1 }\end{array}$ & & $\begin{array}{c}-0.006 * * \\
(0.003)\end{array}$ & $\begin{array}{c}-0.008 * * \\
(0.003)\end{array}$ & $\begin{array}{l}-0.006 \\
(0.006)\end{array}$ & $\begin{array}{c}0.008 \\
(0.007)\end{array}$ & $\begin{array}{l}-0.011 \\
(0.008)\end{array}$ & $\begin{array}{l}-0.003 \\
(0.004)\end{array}$ \\
\hline $\begin{array}{l}\text { US_Cum_CapReq_t } * \\
\text { Tier1 Ratio_t-1 }\end{array}$ & & $\begin{array}{c}0.005^{* *} \\
(0.002)\end{array}$ & $\begin{array}{c}0.003 \\
(0.002)\end{array}$ & $\begin{array}{l}0.007 * \\
(0.003)\end{array}$ & $\begin{array}{l}-0.004 \\
(0.003)\end{array}$ & $\begin{array}{c}0.007 \\
(0.004)\end{array}$ & $\begin{array}{l}.0002 \\
(0.003)\end{array}$ \\
\hline $\begin{array}{l}\text { US_Cum_CapReq_t }{ }^{*} \\
\text { Core Deposits Ratio_t-1 }\end{array}$ & & $\begin{array}{c}0.001^{* * *} \\
(0.000)\end{array}$ & $\begin{array}{l}0.001^{* *} \\
(0.000)\end{array}$ & $\begin{array}{c}0.001^{* *} \\
(0.000)\end{array}$ & $\begin{array}{c}.0001 \\
(0.001)\end{array}$ & $\begin{array}{c}0.001^{* *} \\
(0.000)\end{array}$ & $\begin{array}{c}.0001 \\
(0.001)\end{array}$ \\
\hline Log Total Assets_t-1 & $\begin{array}{l}-0.014 \\
(0.013)\end{array}$ & $\begin{array}{l}-0.016 \\
(0.014)\end{array}$ & $\begin{array}{l}-0.008 \\
(0.011)\end{array}$ & $\begin{array}{l}-0.012 \\
(0.012)\end{array}$ & $\begin{array}{c}0.02 \\
(0.024)\end{array}$ & $\begin{array}{l}-0.035 \\
(0.024)\end{array}$ & $\begin{array}{c}0.008 \\
(0.017)\end{array}$ \\
\hline Tier1 Ratio_t-1 & $\begin{array}{l}0.003 * \\
(0.002)\end{array}$ & $\begin{array}{c}0.002 \\
(0.002)\end{array}$ & $\begin{array}{c}0.002 \\
(0.001)\end{array}$ & $\begin{array}{c}0.001 \\
(0.003)\end{array}$ & $\begin{array}{l}0.003^{*} \\
(0.002)\end{array}$ & $\begin{array}{c}0.005 \\
(0.004)\end{array}$ & $\begin{array}{c}0.001 \\
(0.002)\end{array}$ \\
\hline Illiquid Assets Ratio_t-1 & $\begin{array}{c}0.001^{* *} \\
(0.001)\end{array}$ & $\begin{array}{c}0.001^{* *} \\
(0.001)\end{array}$ & $\begin{array}{c}0.001 \\
(0.001)\end{array}$ & $\begin{array}{c}0.001 \\
(0.001)\end{array}$ & $\begin{array}{c}0.001 \\
(0.001)\end{array}$ & $\begin{array}{c}0.001 \\
(0.001)\end{array}$ & $\begin{array}{c}0.001 \\
(0.001)\end{array}$ \\
\hline International Activity_t-1 & $\begin{array}{c}-0.002 * * * \\
(0.001)\end{array}$ & $\begin{array}{c}-0.002^{* * *} \\
(0.001)\end{array}$ & $\begin{array}{c}-0.002 * * * \\
(0.000)\end{array}$ & $\begin{array}{c}-0.002^{* * *} \\
(0.001)\end{array}$ & $\begin{array}{c}-0.002^{* * *} \\
(0.001)\end{array}$ & $\begin{array}{c}-0.003^{* *} \\
(0.001)\end{array}$ & $\begin{array}{l}-0.002 * \\
(0.001)\end{array}$ \\
\hline Net Due To_t-1 & $\begin{array}{c}0.001 \\
(0.002)\end{array}$ & $\begin{array}{c}0.001 \\
(0.002)\end{array}$ & $\begin{array}{c}0.002 \\
(0.002)\end{array}$ & $\begin{array}{c}0.002 \\
(0.002)\end{array}$ & $\begin{array}{c}0.004 \\
(0.003)\end{array}$ & $\begin{array}{c}0.001 \\
(0.002)\end{array}$ & $\begin{array}{l}0.004 * \\
(0.002)\end{array}$ \\
\hline Core Deposits Ratio_t-1 & $\begin{array}{l}-.0004 \\
(0.001)\end{array}$ & $\begin{array}{l}-0.001 \\
(0.001)\end{array}$ & $\begin{array}{l}-0.001 \\
(0.001)\end{array}$ & $\begin{array}{l}-0.001 \\
(0.001)\end{array}$ & $\begin{array}{c}.0002 \\
(0.001)\end{array}$ & $\begin{array}{l}-0.001 \\
(0.001)\end{array}$ & $\begin{array}{c}-0.001 \\
(0.001)\end{array}$ \\
\hline BIS financial cycle_t & $\begin{array}{c}0.003^{* * *} \\
(0.001)\end{array}$ & $\begin{array}{c}0.004^{* * *} \\
(0.001)\end{array}$ & & & & & \\
\hline BIS business cycle_t & $\begin{array}{c}.0002 \\
(0.000) \\
\end{array}$ & $\begin{array}{c}.0001 \\
(0.000) \\
\end{array}$ & & & & & \\
\hline Observations & 31,733 & 28,464 & 31,857 & 21,981 & 9,876 & 17,071 & 14,786 \\
\hline R-Squared & 0.01 & 0.01 & 0.13 & 0.18 & 0.3 & 0.22 & 0.22 \\
\hline Country-time FE & No & No & Yes & Yes & Yes & Yes & Yes \\
\hline
\end{tabular}




\section{Table A1: Construction of Balance Sheet Variables for the United States}

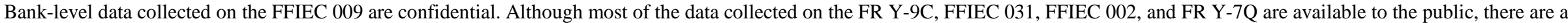
small number of series that are confidential. In the case of the FR Y-7Q, a reporting foreign banking organization may request confidential treatment for its bank-level information.

\begin{tabular}{|c|c|c|c|c|c|}
\hline $\begin{array}{l}\text { Variable } \\
\text { Name }\end{array}$ & Report Form Description & Outward/Inwards - US Global Banks: Source & US Subsidiaries of Foreign Banks: Source & $\begin{array}{l}\text { US Branches of } \\
\text { Foreign Banks: } \\
\text { Source } \\
\end{array}$ & Notes \\
\hline$\Delta \mathrm{Y}$ & $\begin{array}{l}\text { Outward: } \log \left(\text { Total Claims }_{\mathrm{t}}\right)- \\
\log (\text { Total Claims } \\
\left.\text { Inward: }_{\mathrm{t}}\right) \\
\left.\text { Loans }_{\mathrm{t}-1}\right)\end{array}$ & $\begin{array}{l}\text { FFIEC } 009 \\
\text { FCEX C918, C919, C920, C922, 8593, 8577, 8578, } \\
\text { 8579, C915, C916, C917 }\end{array}$ & $\begin{array}{l}\text { FR Y-9C, FFIEC } 031 \\
\text { BHCK and RCFD } 2122\end{array}$ & $\begin{array}{l}\text { FFIEC } 002 \\
\text { RCFD } 2122\end{array}$ & \\
\hline $\begin{array}{l}\text { Illiquid } \\
\text { Assets } \\
\text { Ratio_t-1 }\end{array}$ & $\begin{array}{l}\text { \{(Loans held for sale }+ \text { Loans net of } \\
\text { unearned income and allowances for } \\
\text { loan \& lease losses (A.L.L.) + Held- } \\
\text { to-maturity MBS, ABS, and } \\
\text { structured financial products } \\
\text { (amortized cost) + Available-for-sale } \\
\text { MBS, ABS, and structured financial } \\
\text { products (fair value))/Assets }{ }^{*} 100\end{array}$ & $\begin{array}{l}\text { FR Y9-C, FFIEC 031 } \\
\text { BHCK and RCFD 5369, B529, B838, B841, B842, } \\
\text { B845, B846, B849, B850, B853, B854, B857, B858, } \\
\text { B861, G300, G303, G304, G307, G308, G311, G312, } \\
\text { G315, G316, G319, G320, G323, G324, G327, G328, } \\
\text { G331, K142, K145, K146, K149, K150, K153, K154, } \\
\text { K157, 1698, 1703, 1709, 1714, 1718, 1733, 1702, } \\
\text { 1707, 1713, 1717, 1732, 1736 }\end{array}$ & $\begin{array}{l}\text { FR Y9-C, FFIEC } 031 \\
\text { BHCK and RCFD 5369, B529, B838, B841, } \\
\text { B842, B845, B846, B849, B850, B853, B854, } \\
\text { B857, B858, B861, G300, G303, G304, G307, } \\
\text { G308, G311, G312, G315, G316, G319, G320, } \\
\text { G323, G324, G327, G328, G331, K142, K145, } \\
\text { K146, K149, K150, K153, K154, K157, 1698, } \\
\text { 1703, 1709, 1714, 1718, 1733, 1702, 1707, 1713, } \\
\text { 1717, 1732, 1736 }\end{array}$ & $\begin{array}{l}\text { FFIEC } 002 \\
\text { RCFD G483, 1754, } \\
1773,2122,2170,3195\end{array}$ & $\begin{array}{l}\text { Structured financial products } \\
\text { available on the FR Y9-C } \\
\text { report form starting 2009q2. }\end{array}$ \\
\hline $\begin{array}{l}\text { Log Total } \\
\text { Assets_t-1 }\end{array}$ & $\begin{array}{l}\text { Log (Total assets*(GDP } \\
\text { Deflator }_{2012} / \text { GDP Deflator)) }\end{array}$ & $\begin{array}{l}\text { FR Y9-C, FFIEC 031, BEA } \\
\text { BHCK 2170, RCFD } 2170\end{array}$ & $\begin{array}{l}\text { FR Y9-C, FFIEC 031, BEA } \\
\text { BHCK 2170, RCFD } 2170\end{array}$ & $\begin{array}{l}\text { FFIEC 002, BEA } \\
\text { RCFD } 2170\end{array}$ & $\begin{array}{l}\text { Nominal assets are converted } \\
\text { to } 2012 \text { dollars using the } \\
\text { GDP implicit price deflator } \\
\text { series from the BEA. }\end{array}$ \\
\hline $\begin{array}{l}\text { Core Deposits } \\
\text { Ratio_t-1 }\end{array}$ & $\begin{array}{l}\text { (Total transaction accounts + } \\
\text { Savings deposits (MMDAs, etc.) }+ \\
\text { Total time deposit accounts with } \\
\text { balances less than } \\
\$ 100,000) / \text { Liabilities }\} * 100 \\
\end{array}$ & $\begin{array}{l}\text { FR Y9-C, FFIEC } 031 \\
\text { BHCB 2210, 2389, 3187, 6648, BHOD 3187, 3189, } \\
\text { 2389, 6648, RCON 2215, 2385, 2604. BHCK and } \\
\text { RCFD 2948 }\end{array}$ & $\begin{array}{l}\text { FFIEC } 031 \\
\text { RCON 2215, 2385, } 2604\end{array}$ & $\begin{array}{l}\text { FFIEC 002 } \\
\text { RCON 1653, 2385, } \\
\text { 2604, RCFD 2950 }\end{array}$ & \\
\hline $\begin{array}{l}\text { Tier1 Ratio_t- } \\
1\end{array}$ & $\begin{array}{l}\text { (Tier } 1 \text { risk-based capital/Risk- } \\
\text { weighted assets (net of allowances } \\
\text { and other deductions))*100 }\end{array}$ & $\begin{array}{l}\text { FR Y9-C, FFIEC 031 } \\
\text { BHCA and RCFD 8274, A223 }\end{array}$ & $\begin{array}{l}\text { FR Y9-C, FFIEC 031 } \\
\text { BHCA and RCFD 8274, A223 }\end{array}$ & $\begin{array}{l}\text { FR Y-7Q } \\
\text { FBOQ 8274, A223 }\end{array}$ & $\begin{array}{l}\text { Linear interpolation is used } \\
\text { for FR Y-7Q data }\end{array}$ \\
\hline $\begin{array}{l}\text { Net Due } \\
\text { To_t-1 }\end{array}$ & $\begin{array}{l}\text { ((Net due to own foreign offices, } \\
\text { edge and agreement subsidiaries, and } \\
\text { IBFs - Net due from own foreign } \\
\text { offices, edge and agreement } \\
\text { subsidiaries, and IBFs)/Assets)*100 }\end{array}$ & $\begin{array}{l}\text { FFIEC 009, FR Y-9C, FFIEC } 031 \\
\text { FCEX 8595, BHCK and RCFD } 2170\end{array}$ & $\begin{array}{l}\text { FFIEC } 031 \\
\text { RCON 2941, 2163, RCFD } 2170\end{array}$ & $\begin{array}{l}\text { FFIEC } 002 \\
\text { RCFD 2170, 2154, } 2944\end{array}$ & $\begin{array}{l}\text { From the perspective of the } \\
\text { commercial bank head office } \\
\text { vis-a-vis own foreign offices, } \\
\text { edge and agreement } \\
\text { subsidiaries, and IBFs. }\end{array}$ \\
\hline $\begin{array}{l}\text { International } \\
\text { Activity_t-1 }\end{array}$ & $\begin{array}{l}\text { ((Foreign Assets +Deposits in } \\
\text { foreign offices, edge and agreement } \\
\text { subsidiaries, and IBFs)/Assets)*100 }\end{array}$ & $\begin{array}{l}\text { FFIEC 009, FR Y-9C, FFIEC } 031 \\
\text { FCEX C918, C919, C920, C922, 8577, 8578, 8579, } \\
\text { BHDM 6631, 6636, RCFN 2200, BHCK and RCFD } \\
2170\end{array}$ & $\begin{array}{l}\text { FR Y-9C, FFIEC } 031 \\
\text { BHDM and RCFN 6631, } 6636\end{array}$ & & \\
\hline
\end{tabular}


Table A2: Additional Results on the Effect of Capital Requirements: Split between Domestic and Foreign Lending

This table reports the effects of changes in capital requirements, splitting total loans into loans to U.S. (column 2) and foreign (column 3) residents. The sample period is 2000q1 to 2013q3. All specifications include time and bank fixed effects. Standard errors are robust for global banks. ${ }^{* * *}, * *$, and $*$ indicate significance at the $1 \%, 5 \%$, and $10 \%$ level, respectively.

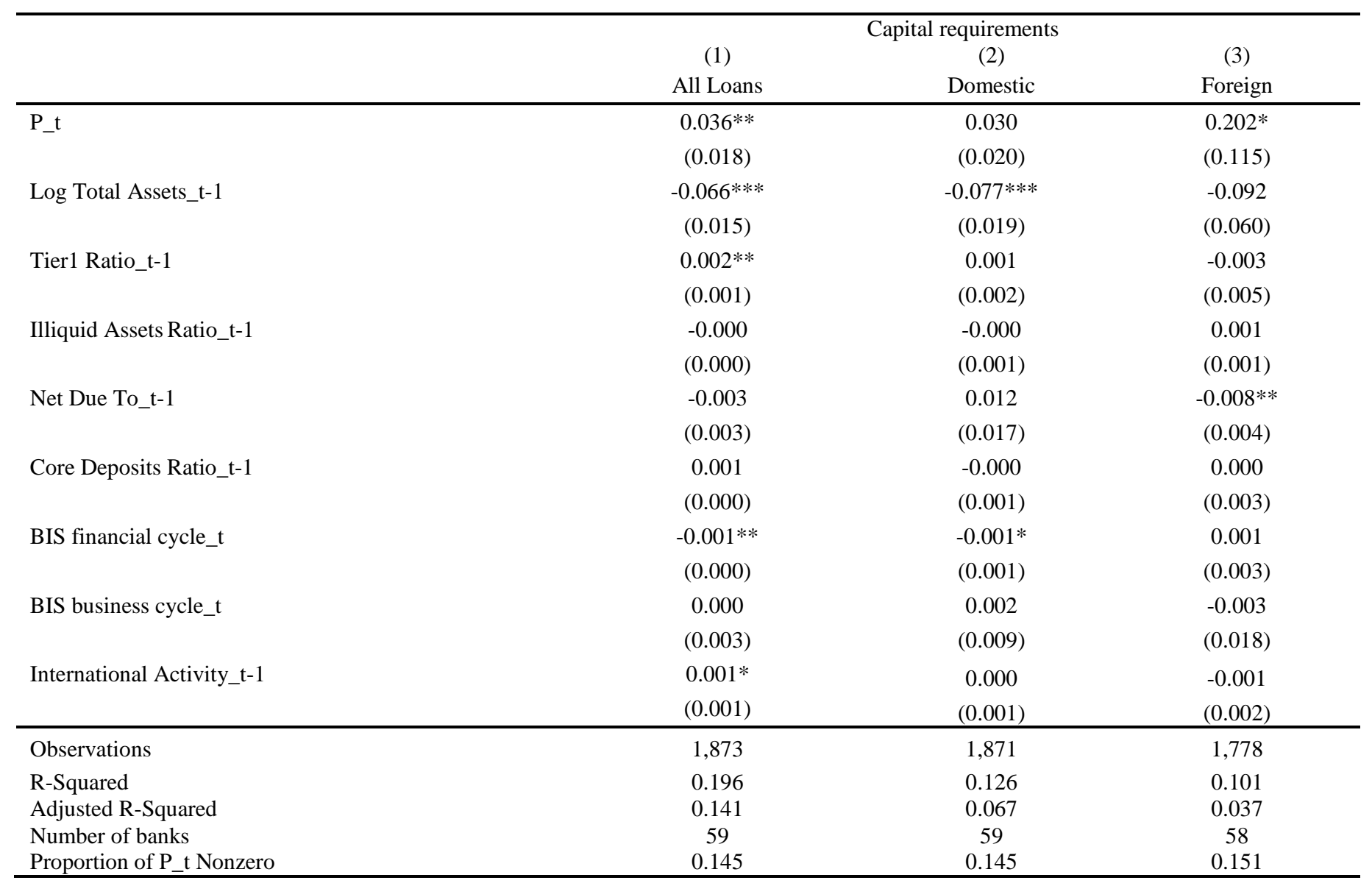

